\title{
Plúton Serra da Garganta como registro de magmatismo cálcio-alcalino no Domínio Rio Piranhas - Seridó, Nordeste da Província Borborema
}

\author{
Marcos Antonio Leite do NASCIMENTO ${ }^{1}$, Vladimir Cruz de MEDEIROS ${ }^{2}$, Antonio Carlos GALINDO ${ }^{1}$ \\ \& Carlos José ARCHANJO ${ }^{3}$
}

\begin{abstract}
${ }^{1}$ Departamento de Geologia, Pós-Graduação em Geodinâmica e Geofísica, Universidade Federal do Rio Grande do Norte. Campus Universitário, S/N, Caixa Postal 1678, CEP 59078-970, Natal, RN, Brasil (marcos@geologia.ufrn.br; galindo@geologia.ufrn.br).

${ }^{2}$ Serviço Geológico do Brasil, Superintendência Regional de Recife, Núcleo de Apoio de Natal. Rua Professor Antônio Henrique de Melo, 2010, Capim Macio, CEP 59.078-580, Natal, RN, Brasil (vladimir.medeiros@cprm.gov.br).

${ }_{3}^{3}$ Instituto de Geociências, Universidade de São Paulo. Rua do Lago, 562, Cidade Universitária, CEP 05508-080, São Paulo, SP, Brasil (archan@usp.br).
\end{abstract}

Nascimento, M.A.L. do, Medeiros, V.C. de, Galindo, A.C. \& Archanjo, C.J. 2018. Plúton Serra da Garganta como registro de magmatismo cálcio-alcalino no Domínio Rio Piranhas - Seridó, Nordeste da Província Borborema. Pesquisas em Geociências, 45: e0620. DOI: https://doi.org/10.22456/1807-9806.85638

Resumo. Existe um intenso plutonismo ediacarano, relacionado ao ciclo Brasiliano/Pan-Africano na Província Borborema, denotado por inúmeros corpos de natureza química diferente. 0 Plúton Serra da Garganta, situado na porção central do Domínio Rio Piranhas-Seridó, extremo NE desta Província, foi alvo de estudos cartográfico, petrográfico, de química mineral, litoquímico e geocronológico (U-Pb, zircão), com o objetivo de definir a filiação magmática e a idade de cristalização. 0 PSG é individualizado em duas fácies: (i) biotita granodiorito a tonalito cinza claro, equigranular, fino a médio; contém K-feldspato, plagioclásio (oligoclásio - An25-23\%), quartzo e biotita (máfico principal), tendo ainda anfibólio, titanita, epídoto e allanita como acessórios; pequenos cristais de minerais opacos, zircão e apatita estão presentes; e (ii) anfibólio biotita quartzo diorito cinza escuro, equigranular, fino, constituído por plagioclásio, quartzo e K-feldspato; biotita é o principal máfico seguido por anfibólio e titanita, tendo epídoto, minerais opacos, allanita, zircão e apatita como acessórios. É comum observar feições de campo indicando coexistência de magmas. Dados litoquímicos para ambas as fácies evidenciam natureza transicional entre metaluminosa e peraluminosa, com afinidade de rochas cálcio-alcalinas, o que não é comum para corpos plutônicos no extremo NE da Província Borborema. A datação U-Pb, para a fácies principal, de 598ะ5 Ma (MSWD = 0,37) obtida em zircões (Shrimp) confirma idade ediacarana para sua cristalização.

Palavras-chave. Província Borborema, Serra da Garganta, Petrologia, Cálcio-alcalino, Geocronologia.

\begin{abstract}
Serra da Garganta Pluton as REcord of CAlC-AlKaline magmatism in Rio Piranhas Seridó Domain, Northeastern of Borborema Province. There is an intense Ediacaran plutonism, related to the Brasilian/Pan African cycle in Borborema Province, denoted by numerous bodies of different chemical nature. The Serra da Garganta Pluton, located within the central portion of the Rio Piranhas-Seridó Domain, was the subject of cartographic, petrographic, chemical (whole rock and mineral) and geochronologic (zircon U-Pb) studies, in order to characterize its magmatic affiliation and crystallization age. The rocks that build up the SGP are grouped into two petrographic facies: (i) equigranular, fine- to medium-grained, gray-colored biotite tonalites to granodiorites with K-feldspar (microcline), oligoclase (An23-25), quartz, and biotite as the main mafic mineral; accessory minerals are amphibole, titanite, epidote, and allanite, as well as minute and rare crystals of opaque minerals, zircon, and apatite; and, (ii) equigranular, fine-grained, dark-gray-colored amphibole biotite quartz diorites with plagioclase, quartz, K-feldspar, and biotite as the chief minerals, with minor contents of amphibole and titanite; accessory phases are epidote, opaque minerals, allanite, and traces of zircon and apatite. It is common to observe field features indicating coexistence of magmas. The obtained results reveal rocks from both facies are metaluminous to peraluminous, with affinity of calc-alkaline rocks, which is not common for plutonic bodies in the extreme NE of Borborema Province. The U-Pb dating, for the main facies, of the $598 \pm 5 \mathrm{Ma}(\mathrm{MSWD}=0.37$ ) obtained in zircons (Shrimp) confirms Ediacaran age for its crystallization.
\end{abstract}

Keywords. Borborema Province, Serra da Garganta, Petrology, Calk-alkaline, Geochronology. 


\section{Introdução}

No Domínio Rio Piranhas - Seridó da Província Borborema (Almeida et al., 1981), extremo Nordeste do Brasil, existe um intenso plutonismo ediacarano, relacionado ao ciclo Brasiliano/Pan-Africano. Tal plutonismo ocorre de diversas formas, com destaque para batólitos, stocks e diques. Associado a esse plutonismo, observa-se uma considerável variação petrográfica e química, sendo ao longo dos anos, com a evolução do conhecimento sobre dados petrográficos, químicos e geocronológicos, discutidas tentativas de classificação e agrupamento para as rochas desse magmatismo.

Almeida et al. (1967) foram os primeiros a propor classificação posicionando essas rochas com relação ao Ciclo Brasiliano, classificando-as em: a) Granitoides Sin-tectônicos / tipos Itaporanga (porfirítico) e Conceição (equigranular); b) Tardi-Tectônicos / tipos Catingueira e Itapetim.

Décadas depois, Jardim de Sá et al. (1981), restringindo-se ao então Domínio Seridó, propuseram uma classificação das rochas granitoides baseada em parâmetros estruturais, classificando-as em: Gx (rochas básicas e intermediárias), G3 (granodioritos porfiríticos ou equigranulares) e G4 (leucogranitos tardios). Já com base no uso de dados geoquímicos, Sial (1987) individualizou quatro grupos de granitoides na Província Borborema, descrevendo-os como Calcioalcalino potássica, Calcioalcalina, Trondhjemítica e Peralcalina.

Jardim de Sá (1994) definiu as suítes Básicas a Intermediárias, Porfiríticas e Leucograníticas para o extremo Nordeste da Província Borborema. Galindo et al. (1997a, 1997b) adicionaram as suítes Shoshonítica e Alcalina àquelas então definidas por Jardim de Sá (1994). Ferreira et al. (1998), com base em dados petrográficos e químicos, reconheceram nove grupos de rochas granitoides e sienogranitoides na Província Borborema. Dos nove grupos, seis são observados nos domínios Rio Piranhas - Seridó e São José de Campestre: Shoshoníticos, Calcioalcalino de alto K com e sem epídoto magmático, Calcioalcalino com epídoto magmático, Calcioalcalino peraluminoso e Peralcalino.

Angelim et al. (2006), ao integrarem dados já existentes na literatura, agruparam as rochas granitoides dos domínios Jaguaribeano, Rio Pira- nhas - Seridó e São José de Campestre, em cinco suítes denominadas de São João do Sabugi, Itaporanga, Dona Inês, Catingueira e Umarizal.

Mais recentemente, Nascimento et al. (2015), lançando mão de dados da literatura, utilizaram características químicas, petrográficas/texturais e geocronológicas, identificando seis suítes plutônicas nos domínios Rio Piranhas - Seridó e São José de Campestre. A nomenclatura para definir cada suíte reflete sua afinidade magmática, sendo denominadas de Shoshonítica; Calcioalcalina de alto $\mathrm{K}$ porfirítica; Calcioalcalina de alto $\mathrm{K}$ equigranular; Calcioalcalina; Alcalina; Alcalina Charnockítica. Contudo, é importante salientar que rochas da suíte Calcioalcalina passaram a ser descritas há pouco tempo e dentro do contexto desse imenso plutonismo representam, até o momento, apenas três corpos - Gameleira (Oliveira et al., 2014), Serra Verde (Costa et al., 2015) e Serra da Garganta (este artigo).

Assim, por tratar-se de um corpo com características distintas das suítes magmáticas ediacaranas até então referidas no Domínio Rio Piranhas - Seridó, o Plúton Serra da Garganta foi alvo de estudos detalhados de petrografia, química mineral, litoquímica e geocronologia, no intuito de definir sua assinatura magmática, permitindo contribuir para o estudo das suítes ígneas da região. Os estudos geocronológicos tiveram ainda como objetivos a determinação da idade do alojamento do corpo, bem como a idade limite para a deposição da Formação Seridó na região, tendo em vista que o plúton é intrusivo nesta unidade.

\section{2 Área, materiais e métodos}

A área encontra-se inserida na porção setentrional da Província Borborema, no Domínio Rio Piranhas - Seridó, o qual é limitado a sul, leste e oeste, respectivamente, pelas zonas de cisalhamento Patos, Picuí-João Câmara e Portalegre, enquanto o limite norte desse domínio está encoberto por rochas sedimentares fanerozoicas da Bacia Potiguar (Fig. 1).

\subsection{Contexto geológico regional}

De acordo com Angelim et al. (2006), o 
Domínio Rio Piranhas - Seridó caracteriza-se pela presença de rochas metaplutônicas e metavulcanossedimentares de idade paleoproterozoicas (Riaciana), correlacionáveis na literatura ao Complexo Caicó, incluindo, ainda, uma suíte de augen gnaisses granítica também paleoproterozoica (Orosiriana), as quais compõem o embasamento para as rochas supracrustais neoproterozoicas do Grupo Seridó. Este engloba as formações Jucurutu (predominando paragnaisses com lentes de mármores e calciossilicáticas associadas), Equador (quartzitos e metaconglomerados associados) e Seridó (predomínio de micaxistos), sendo essas litologias intrudidas por inúmeros corpos ígneos, de composição química distinta, associados ao plutonismo ediacarano, incluindo o Plúton Serra da Garganta. Por fim, no interior do Domínio Rio Piranhas - Seridó, contudo não exclusivo a ele, são identificadas rochas vulcânicas mesozoicas e cenozoicas associadas aos vulcanismos Rio CearáMirim e Macau, além de coberturas cenozoicas.

\subsection{Materiais e métodos}

As rochas pertinentes ao Plúton Serra da Garganta foram objeto de estudo petrográfico em 17 seções delgadas, sendo 10 da fácies granodiorítica/tonalítica e 7 da fácies diorítica. Para a nomenclatura dessas rochas foram consideradas as recomendações segundo os critérios da IUGS, conforme Streckeisen (1976). Para obter as porcentagens modais, foram realizadas contagens de 1000 pontos por seção delgada, utilizando um microscópio petrográfico Leica DMLP com contador de pontos eletrônico acoplado, controlado via computador pelo aplicativo PETROG v. 2.45, da Conwy Valley Systems Ltda.

Os dados de química mineral em biotita, anfibólio, titanita e feldspatos (K-feldspato e plagioclásio), de uma amostra da fácies granodiorítica/tonalítica (ML-55 - um anfibólio-biotita granodiorito) foram realizadas no Laboratório de Microssonda Eletrônica (LME) do IG/UnB, em um

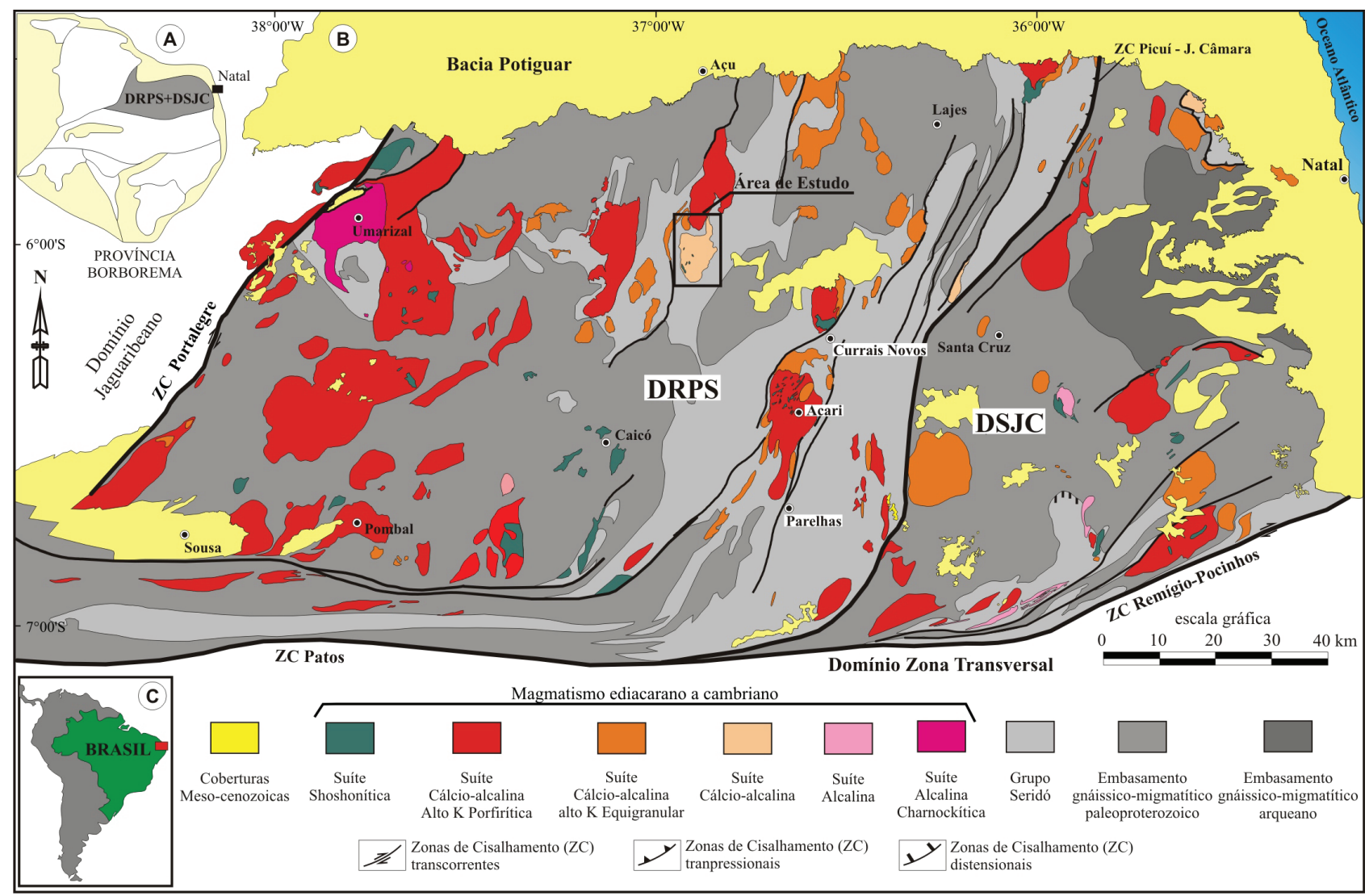

Figura 1. Arcabouço geológico do extremo nordeste da Província Borborema (NE do Brasil). A) Domínios Rio Piranhas - Seridó (DRPS) e São José de Campestre (DSJC) na Província Borborema (Medeiros, 2013); B) Unidades geológicas com destaque para o magmatismo Ediacarano a Cambriano (modificado de Nascimento et al., 2015); C) Localização da área de estudo no extremo nordeste do Brasil.

Figure 1. Geological framework of the extreme northeastern Borborema Province (NE Brazil). A) the Rio Piranhas - Seridó (RPSD) and the São José de Campestre (SJCD) domains in the Borborema Province (Medeiros, 2013); B) Geological units with emphasis Ediacaran to Cambrian magmatism (modified from Nascimento et al., 2015); C) Location of the study area in the northeast of Brazil. 
equipamento Jeol, modelo Superprobe JXA-8230. As condições analíticas para os silicatos foram 15 $\mathrm{Kv}$ de energia e $10 \mathrm{nA}$ de corrente.

Os dados de litoquímica incluem elementos maiores e traços em 16 amostras (9 para a fácies granodiorítica/tonalítica e 7 para a fácies diorítica) e terras raras para 12 amostras ( 6 para a fácies granodiorítica/tonalítica e 6 para a fácies diorítica). As amostras foram analisadas para elementos maiores (método de ICP-OES - Espectrometria de Emissão Atômica com Plasma Acoplado Indutivamente), traços e terras raras (método ICP-MS - Espectometria de Massas com Plasma Acoplado Indutivamente) após fusão por metaborato/tetraborato de lítio e digestão ácida na ACME Analytical Laboratories Ltda. (Vancouver, Canadá). A perda ao fogo foi calculada pela diferença de peso após aquecer $0,2 \mathrm{~g}$ de amostra a $1000^{\circ} \mathrm{C}$. 0 erro analítico é menor que $5 \%$ para os óxidos e de $2 \%$ para os elementos traços.

Por fim, para estudos geocronológicos a escolha dos zircões foi feita após britagem da amostra e separação na bateia dos minerais mais densos. Os minerais pesados não magnéticos foram separados no Separador Frantz e os zircões decantados utilizando líquidos densos. Em torno de 50 cristais límpidos e aparentemente sem fraturas internas foram escolhidos e montados em resina junto aos zircões de referência TEMORA1 $(206 \mathrm{~Pb} / 238 \mathrm{U}=$ $416,78 \pm$ 0,33 Ma; Black et al., 2004). Após o polimento dos cristais fixados à resina, os grãos são fotografados e suas estruturas internas imageadas por meio de catodoluminescência (CL). 0 imageamento e a análise pontual dos elementos U-Th- $\mathrm{Pb}$ foram feitos no Centro de Pesquisa Geocronológicas da Universidade de São Paulo. As razões isotópicas dos zircões do TEMORA1 da amostra ML-55 (anfibólio-biotita granodiorito) foram determinadas e uma microssonda iônica de alta resolução (SHRIMP IIe; Sato et al., 2014). 0 chumbo comum foi corrigido para o $204 \mathrm{~Pb}$ assumindo o modelo de composição do $\mathrm{Pb}$ de Stacey \& Kramers (1975). Os dados foram reduzidos no SQUID 1.06 e o tratamento estatístico dos resultados utilizando o ISOPLOT v. 3 (Ludwig, 2003). A idade concórdia foi calculada com um erro analítico de $2 \sigma$ enquanto a idade média com um nível de confiança de 95\%.

\section{Resultados}

\subsection{Geologia do Plúton Serra da Garganta}

As rochas do Plúton Serra da Garganta encontram-se exclusivamente intrusivas em rochas metassedimentares da Formação Seridó (Fig. 2), principalmente em unidades de micaxistos por vezes com granada e/ou cordierita e/ou estaurolita e/ou andaluzita (Fig. 3A). Porções destes micaxistos também são encontradas como xenólitos no interior do corpo principal (Fig. 3B), onde geralmente apresentam um crescimento dos cristais de granada, estaurolita e andaluzita, evidenciando metamorfismo de contato com geração de hornfels.

O Plúton Serra da Garganta possui uma área de $120 \mathrm{~km}^{2}$, na região entre as cidades de Florânia e Jucurutu (RN), e também na forma de pequenos corpos satélites. Os dados de campo indicam possuir duas fácies principais, uma de natureza granodiorítica/tonalítica e outra diorítica.

A primeira e principal fácies em área é formada por rochas de composição tonalítica a granodiorítica com biotita e mais raramente cristais de anfibólio, leucocráticas de coloração cinza clara (Fig. 4A), equigranulares de granulometria fina a média, por vezes apresentando concentrações (clots máficos) de biotita e mais raramente de anfibólio, além de enclaves máficos da fácies diorítica (Fig. 4B); ocorrem tanto nas regiões menos elevadas topograficamente, como também constituindo as serras da porção sul e leste do corpo principal.

A segunda fácies corresponde a áreas de predominância de rochas de composição diorítica contendo anfibólio e biotita, de natureza mesocrática, de coloração cinza escura e granulometria fina a média, os quais afloram principalmente nas porções oeste e sudoeste do corpo principal (regiões topograficamente menos elevadas); ocorrem principalmente como enclaves máficos de forma ovalada ou elipsoidal, com dimensões centimétricas a decamétricas (Fig. 4C), mostrando bordas de reação com a fácies granodiorítica/tonalítica. Por vezes observa-se textura de stockwork nestas rochas, com percolação de veios da fácies granodiorítica/tonalítica (Fig. 4D). 


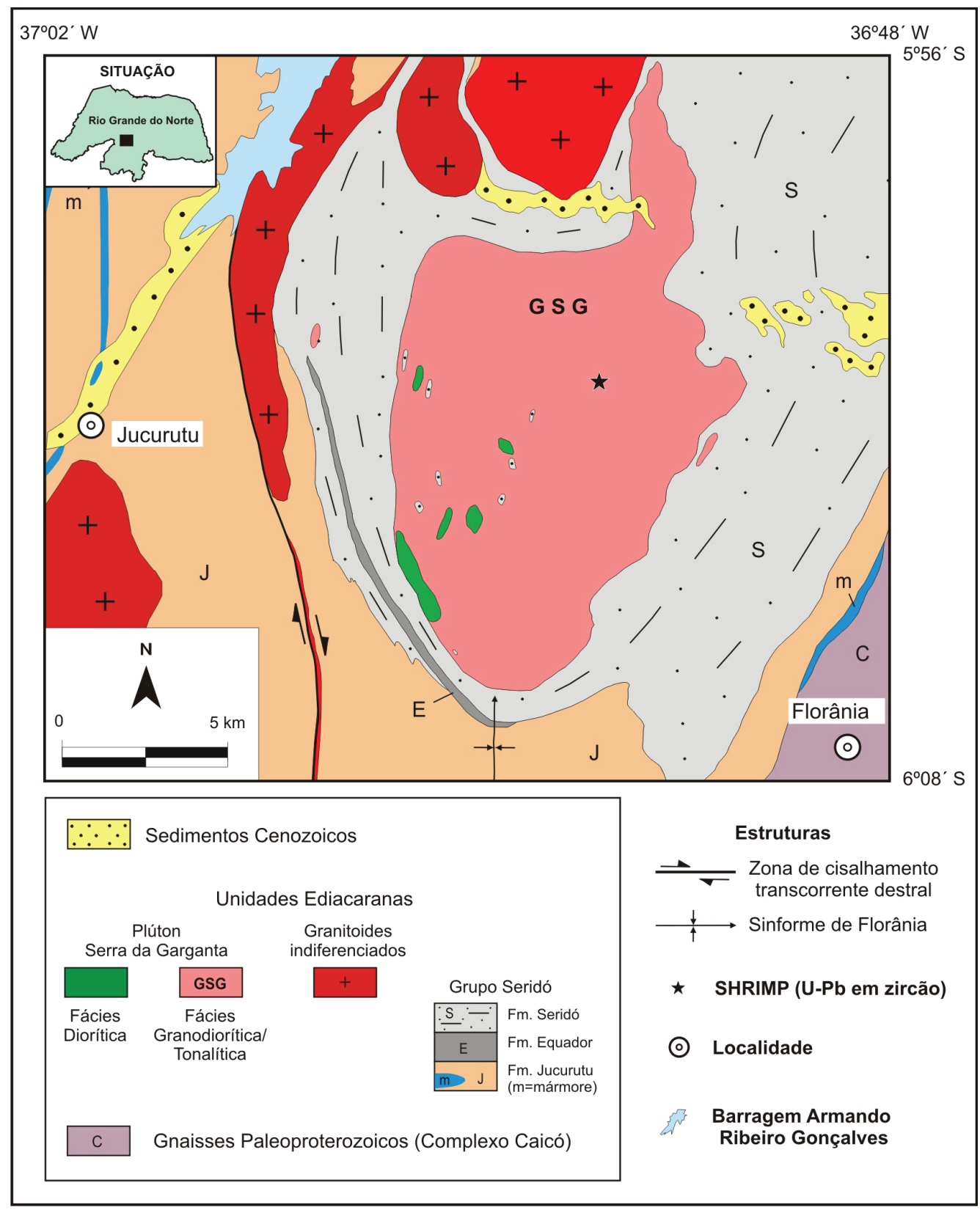

Figura 2. Mapa geológico do Plúton de Serra da Garganta, adaptado de Angelim et al. (2006) e Medeiros et al. (2012). Figure 2. Geological map of Serra da Garganta Pluton, adapted of Angelim et al. (2006) and Medeiros et al. (2012).
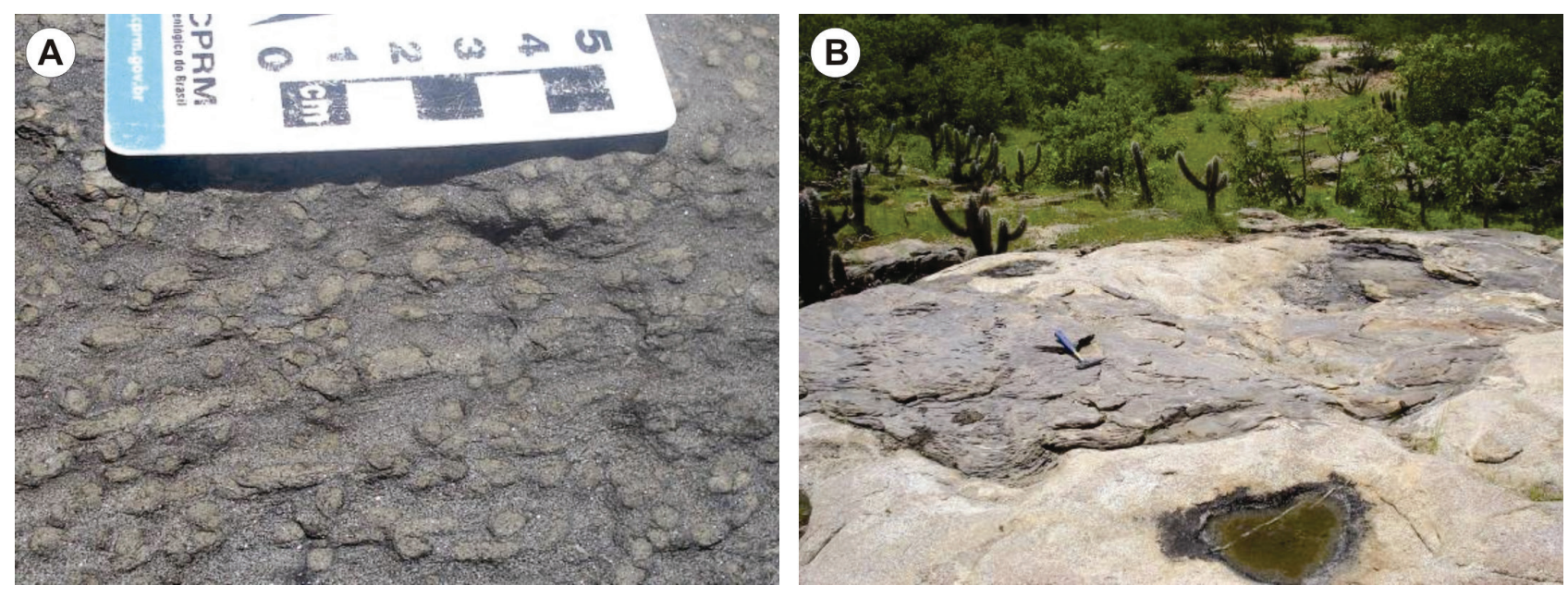

Figura 3. Aspecto de campo das rochas encaixantes do Plúton Serra da Garganta. A) Estaurolita-andaluzita-biotita xisto porfirolepidoblástico da Formação Seridó; B) Xenólito métrico de xisto da Formação Seridó no granodiorito da Serra da Garganta. Figure 3. Field aspect of the host rocks of the Serra da Garganta Pluton. A) Staurolite-andalusite-biotite schist porfirolepidoblastic of the Seridó Formation; B) Metric xenolith of schist of the Formation Seridó in Serra da Garganta granodiorite. 

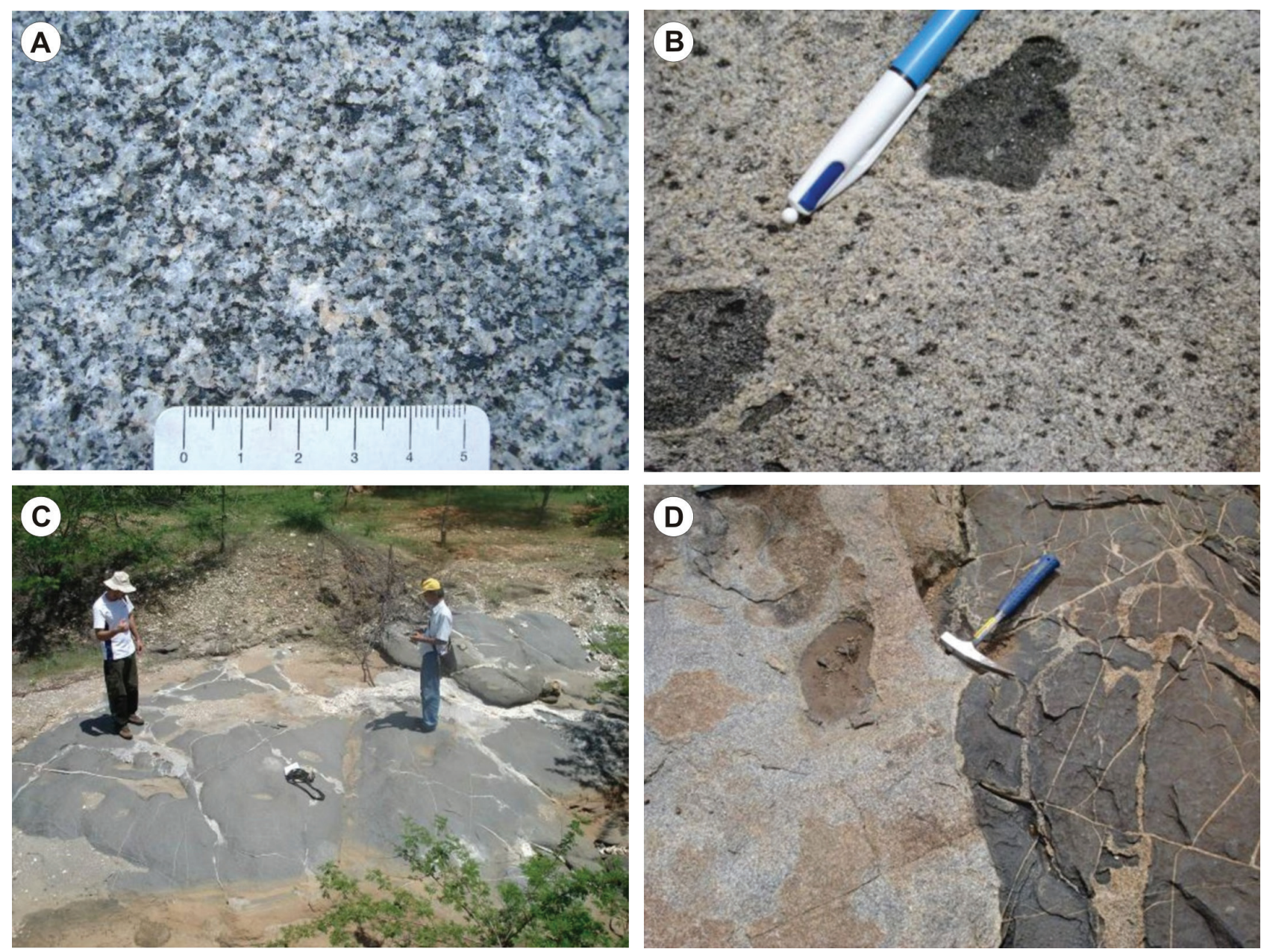

Figura 4. Aspecto de campo das rochas do Plúton Serra da Garganta. A) Fácies principal formada por anfibólio-biotita granodiorito leucocrática; B) Anfibólio-biotita granodiorito leucocrático com enclaves máficos da fácies diorítica, indicando mistura e contraste de viscosidade entre os dois magmas; C) Feição de afloramento do anfibólio-biotita quartzo diorito mesocrático; D) Biotita granodiorito leucocrático, com enclaves e porções dioríticas apresentando textura stockwork.

Figure 4. Field aspect of the Serra da Garganta Pluton. A) Main facies formed by amphibole-biotite leucocratic granodiorite; B) Amphibole-biotite granodiorite leucocratic with mafic enclaves of dioritic facies, indicating mingling and viscosity contrast between the two magmas; C) Outcrop features of amphibole-biotite quartz diorite mesocratic; D) Biotite granodiorite leucocratic with enclaves and dioritic portions with stockwork texture.

\subsection{Petrografia e Química Mineral}

\subsubsection{Petrografia}

As rochas que formam a fácies granodiorítica/tonalítica são leucocráticas ( $\Sigma \mathrm{M}=10-35 \%)$, com plagioclásio, quartzo e K-feldspato constituindo a paragênese félsica e dominante, sempre com o plagioclásio dominando sobre os demais (33$53 \%$ da moda). A biotita é o máfico principal (1031\%), com anfibólio, titanita, epídoto e allanita os principais acessórios. Raros e pequenos cristais de minerais opacos, zircão e apatita podem estar presentes, além de mica branca e carbonatos como fases tardias de alteração (associadas a biotita e plagioclásio, principalmente). Composicionalmente estas rochas são representadas por biotita ( \pm an- fibólio) granodiorito e biotita ( \pm anfibólio) tonalito (Fig. 5, Tab. 1).

O plagioclásio, a fase mineral dominante tanto nos granodioritos quanto nos tonalitos, ocorre como cristais usualmente idio-hipidiomórficos com até $5 \mathrm{~mm}$ de tamanho (eixo maior), ou por vezes como cristais menores $(\approx 0,5-1 \mathrm{~mm})$ hipidiomórficos, compondo agregados. Maclas polissintéticas são comuns, por vezes associadas com Carslbad na mesma face do cristal. No geral os cristais mostram-se fortemente zonados em padrões complexos, zonação normal e oscilatória, sendo ainda observadas texturas tipos synneusis e patchy zoning, além de finas e irregulares bordas albíticas nos cristais menores que ocorrem como agregados (Figs. 6A, B, C e D). A zonação normal é denotada 


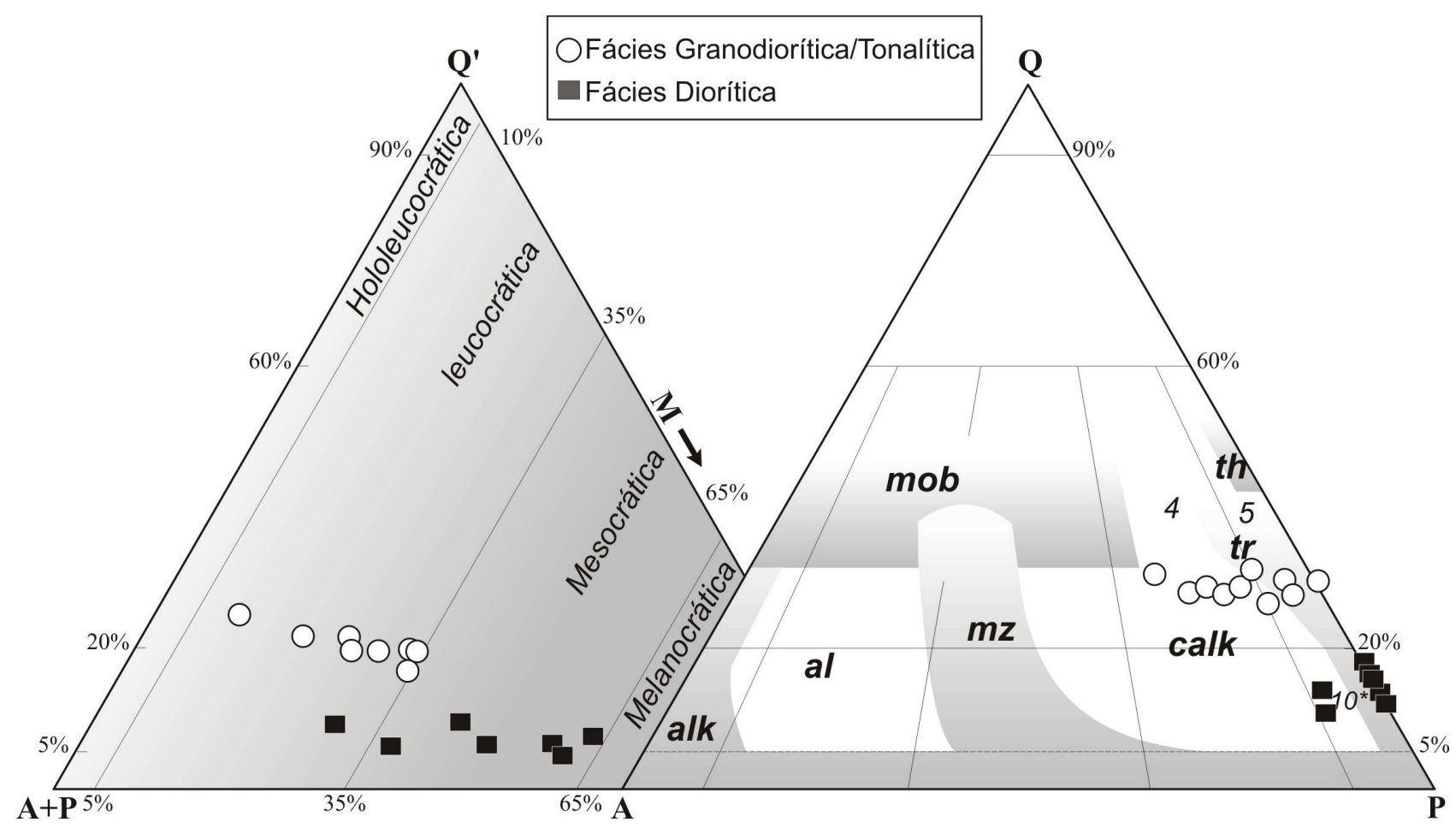

Figura 5. Classificação das rochas plutônicas estudadas nos diagramas QAP e Q(A+P)M (Streckeisen, 1976; Le Maitre, 2002), com os campos/trends para séries de granitoides (Lameyre \& Bowden, 1982), sendo $Q=$ quartzo, $A=$ feldspato alcalino (K-feldspato + plagioclásio com $<5 \% \mathrm{An}), \mathrm{P}=$ plagioclásio $(>5 \% \mathrm{An}), \mathrm{M}=$ total de minerais máficos, $4=$ granodiorito, $5=$ tonalito, $10^{*}=$ quartzo diorito, th = toleítica, $\operatorname{tr}=$ trondhjemítica, calk = calcioalcalina, $\mathrm{mz}=$ monzonítica, al = alcalina aluminosa, alk = alcalina/peralcalina, $\mathrm{mob}=$ mobilizados/granitos crustais.

Figure 5. Classification of plutonic rocks studied on diagrams $Q A P$ and $Q(A+P) M($ Streckeisen, 1976) with field/trends to granitoids series (Lameyre \& Bowden, 1982), with $Q=$ quartz, $A=$ alkaline feldspar (K-feldspar + plagioclase with $<5 \%$ An), $P=$ plagioclase ( $>$ $5 \% \mathrm{An}$ ), $M=$ mafics total, $4=$ granodiorite, $5=$ tonalite, $10^{*}=$ quartz diorite, th = tholeitic, $t r=$ trondhjemitic, calk $=$ calc-alkaline, $m z=$ monzonítica,$a l=$ aluminous alkaline, alk = alkaline $/$ peralkaline, mob = crustal granites.

Tabela 1. Composição modal para as rochas da fácies granodiorítica/tonalítica do Plúton Serra da Garganta. Table 1. Modal combosition to rocks of aranodioritic/tonalitic facies of the Serra da Garaanta Pluton.

\begin{tabular}{|c|c|c|c|c|c|c|c|c|c|c|}
\hline & \multicolumn{10}{|c|}{ Fácies Granodiorítica/Tonalítica } \\
\hline & \multicolumn{5}{|c|}{ Biotita ( \pm Anfibólio) Granodiorito } & \multicolumn{5}{|c|}{ Biotita ( \pm Anfibólio) Tonalito } \\
\hline & ML & ML & $\mathrm{ML}$ & ML & ML & ML & ML & ML & ML & CEBP \\
\hline & 55 & $87 A$ & 429A & $429 C$ & 428 & 413 & $416 A$ & 418 & $422 A$ & 55 \\
\hline Quartzo & 20 & 25 & 22 & 20 & 20 & 17 & 20 & 20 & 22 & 22 \\
\hline K-feldspato & 13 & 15 & 10 & 10 & 7 & 5 & 5 & 3 & --- & 3 \\
\hline $\begin{array}{l}\text { Plagioclási } \\
\text { o }\end{array}$ & 33 & 50 & 48 & 40 & 43 & 43 & 40 & 50 & 53 & 50 \\
\hline Biotita & 15 & 10 & 13 & 28 & 16 & 20 & 31 & 25 & 25 & 22 \\
\hline Anfibólio & 8 & -- & --- & --- & 8 & 8 & --- & --- & --- & -- \\
\hline Titanita & 4 & --- & 2 & 1 & 3 & 4 & 4 & 2 & --- & 3 \\
\hline Epídoto & 5 & -- & 5 & -- & 3 & 1 & -- & --- & -- & -- \\
\hline Allanita & 2 & --- & -- & --- & --- & 2 & -- & $--\cdot$ & -- & --- \\
\hline Opacos & 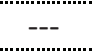 & --- & 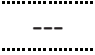 & 1 & ---" & --- & 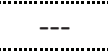 & --- & --- & 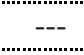 \\
\hline Acessórios & $\mathrm{Tr}$ & $\mathrm{Tr}$ & $\mathrm{Tr}$ & $\mathrm{Tr}$ & $\mathrm{Tr}$ & $\mathrm{Tr}$ & $\mathrm{Tr}$ & $\mathrm{Tr}$ & $\mathrm{Tr}$ & $\mathrm{Tr}$ \\
\hline $\mathbf{Q}$ & 30,3 & 27,8 & 27,5 & 28,6 & 28,6 & 26,2 & 30,8 & 27,4 & 29,3 & 29,3 \\
\hline$A$ & 19,7 & 16,7 & 12,5 & 14,3 & 10,0 & 7,7 & 7,7 & 4,1 & 0,0 & 4,0 \\
\hline $\mathbf{P}$ & 50,0 & 55,6 & 60,0 & 57,1 & 61,4 & 66,2 & 61,5 & 68,5 & 70,7 & 66,7 \\
\hline M & 34,0 & 10,0 & 20,0 & 30,0 & 30,0 & 35,0 & 35,0 & 27,0 & 25,0 & 25,0 \\
\hline
\end{tabular}

Obs. Os acessórios são: zircão, apatita, mica branca e carbonato. 
principalmente por alguns cristais apresentarem, no geral, núcleos bem mais alterados/transformados em relação às bordas (Figs. 6A, B). Os padrões complexos de zonação dificultam a determinação das composições por métodos óticos, entretanto em alguns cristais foram medidas, pelo método de Michel-Levy, composições da ordem de An26-22\%. Os processos de alteração secundária (carbonatação e/ou saussuritização) comuns na maioria dos plagioclásios, também sugerem composições, pelo menos, no campo do oligoclásio cálcico (An >20\%) para esses minerais. É frequente se observar cristais com planos de maclas deformados (vergados e/ou com fraturas deslocando-os), além do desenvolvimento de textura mirmequítica nos contatos com alguns cristais de K-feldspato. Inclusões de biotita, anfibólio, titanita, epídoto, apatita e zircão são comuns.

O K-feldspato ocorre em geral como cristais xeno-hipidiomórficos de bordas irregulares e/ ou corroídas, sendo típicas microclinas com o padrão tartan das maclas albita-periclina, sendo comuns seções com textura pertítica. No K-feldspato ocorrem inclusões de biotita e titanita, e mais raramente anfibólio. 0 quartzo ocorre essencialmente como cristais límpidos, xenomórfico de contatos irregulares e/ou embaiados, no geral fraturado e sempre com extinção ondulante em diferentes padrões (Fig. 6E).

A biotita constitui o principal máfico presente nesta fácies, seguida por anfibólio e titanita. Ocorre como cristais lamelares no geral hipidiomórficos, de contatos retos a serrilhados, cor amarela-esverdeada em seções longitudinais, avermelhada em seções basais, e com forte pleocroísmo em tons de castanho (Fig. 6F). Alguns cristais mostram alteração para clorita e/ou muscovita, com a frente da alteração se desenvolvendo ao longo dos planos de clivagens. Inclusões de epídoto, titanita, allanita, apatita e zircão são comuns.

0 anfibólio é da família das hornblendas, ocorre em cristais prismáticos idiomórficos a hipidiomórficos de cor verde (Fig. 6F), com pleocroísmo em tons de verde amarelado a verde oliva, e com alguns cristais apresentando por vezes geminação simples e/ou composta, tanto em seções longitudinais quanto basais com as duas clivagens em $60^{\circ}-120^{\circ}$. Inclusões de pequenos cristais de biotita, titanita e apatita são comuns.

A titanita aparece principalmente como cristais idiomórficos em seções losangulares e/ou prismáticas alongadas, de cor marrom e com fraco pleocroísmo, fraturados, alguns com as fraturas já preenchidas por material escuro/opaco. Mais raramente têm-se titanita como finas e irregulares coroas sobre minerais opacos (Fig. 6F).

0 epídoto ocorre em cristais idiomórficos, de natureza primária, e inclusos na biotita. São cristais incolores a fracamente coloridos em tons de amarelo e com cores fortes de birrefringência. É comum ainda ocorrer com núcleos de allanita, marrom avermelhada, ambos inclusos na biotita. A allanita aparece como cristais idiomórficos a hipidiomórficos, usualmente com zonação, alguns mostrando textura metamíctica.

Os minerais opacos são poucos e pequenos cristais, no geral idiomórficos (seções quadráticas e/ou losangulares, sugestivas de magnetita) a xenomórficos, estes últimos com finas e irregulares coroas de titanita. Zircão e apatita são pequenos cristais idiomórficos, prismáticos finos (zircão), ou seções hexagonais/arredondadas (apatita), no geral, inclusos em biotita e anfibólio.

As rochas da fácies diorítica são dominantemente mesocráticas $(\Sigma \mathrm{M}=38-62 \%)$ com apenas uma amostra leucocrática ( $\mathrm{M}=30 \%)$, plagioclásio é o mineral félsico dominante (31-55\%) e quartzo (5-10\%) e K-feldspato (0-5\%) compõem as demais fases da paragênese félsica. A biotita é o máfico principal e presente em todas as lâminas (18-30\%), seguida por anfibólio (0-31\%), e titanita, epídoto, minerais opacos e allanita são os principais acessórios. Raros e pequenos cristais de zircão e apatita podem estar presentes. Composicionalmente, estas rochas são essencialmente anfibólio-biotita quartzo dioritos (Fig. 5 e Tab. 2).

Nesta fácies o plagioclásio é também a fase mineral dominante e ocorre em três diferentes aspectos texturais: i) cristais pequenos e alongados/ripiforme $(\leq 0,5 \mathrm{~mm}$ no seu eixo maior) que compõem a matriz da rocha, usualmente apresentando as maclas polissintética e simples (no geral tipos Albita-Carslbad) conjugadas numa mesma face (Fig. 7A); ii) microfenocristais da ordem de 0,5-1,5 mm dispersos na matriz, os quais podem mostrar zonação normal e inversa, além de textura 

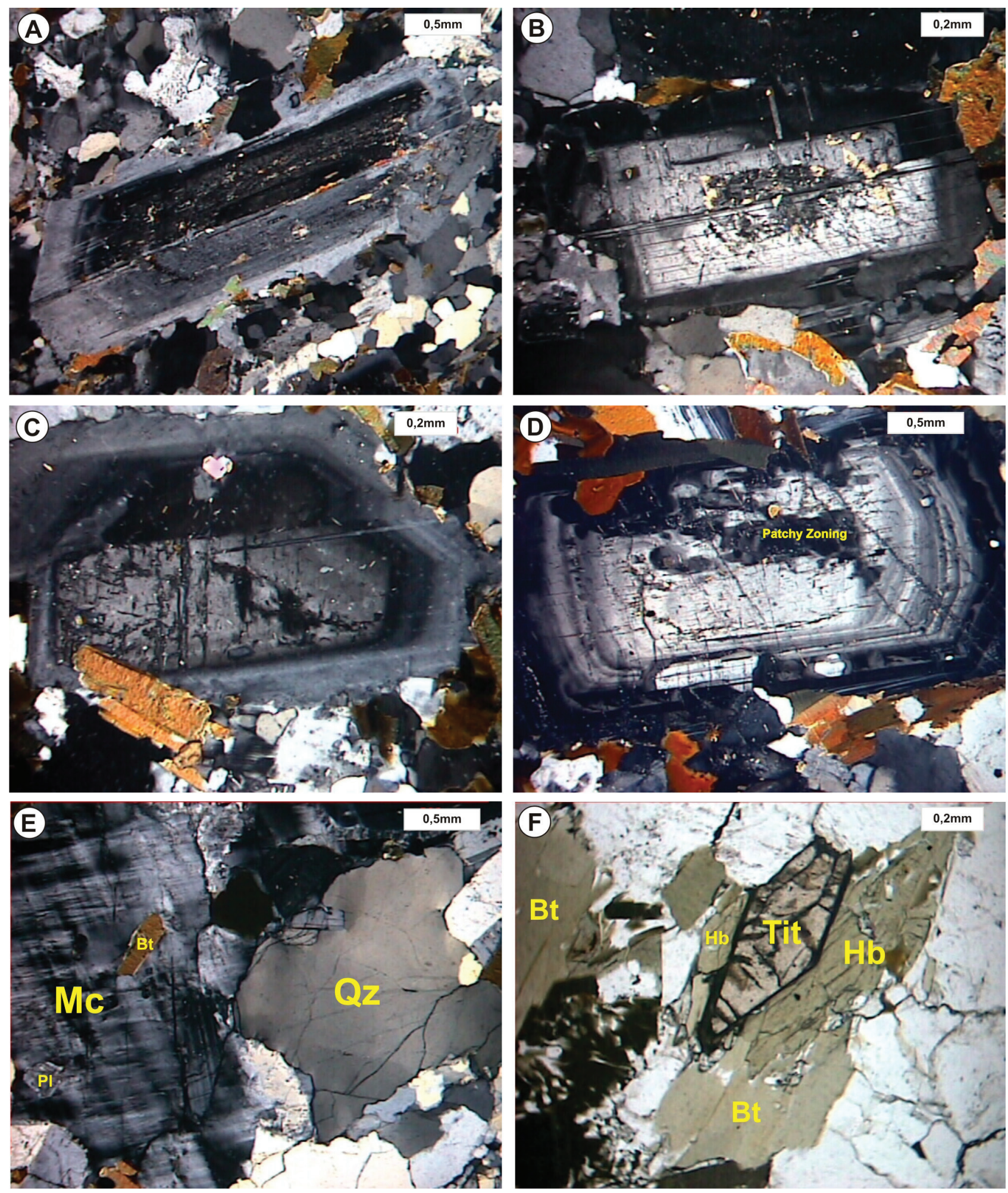

Figura 6. Minerais da fácies granodiorítica/tonalítica. A) Plagioclásio com zonação normal e maclas Carlsbad-Albita conjugadas; B) Plagioclásio com zonação normal e textura synneusis; C e D) Plagioclásios com zonação oscilatória, em D tem ainda patchy zoning; E) Cristais xenomórficos de microclina (Mc) e quartzo com extinção ondulante e fraturado (Qz); F) Agregado máfico com cristais de biotita (Bt), hornblenda (Hb) e titanita (Tit), notar as fraturas da titanita já preenchidas por óxido/hidróxido. Figure 6. Minerals of granodioritic/tonalitic facies: A) Plagioclase with normal zonation and Carlsbad-Albita Maclas; B) Plagioclase with normal zonation and synneusis texture; $C$ and D) Plagioclase with oscillatory zonation, in D still have patchy zoning; E) Xenomorfic crystals of microcline (Mc) and quartz with wavy extinction and fractured (Qz); F) Mafic unit with biotite (Bt), hornblende ( $\mathrm{Hb}$ ) and titanite (Tit) crystals, notice the titanite fractures already filled by oxide/hydroxide. 
Tabela 2. Composições modais para as rochas da fácies diorítica do Plúton Serra da Garganta. Table 2. Modal composition to rocks of dioritic facies of the Serra da Garganta Pluton.

\begin{tabular}{|c|c|c|c|c|c|c|c|}
\hline & \multicolumn{7}{|c|}{ Fácies Diorítica } \\
\hline & \multicolumn{7}{|c|}{ Anfibólio Biotita Quartzo Diorito } \\
\hline & $\mathrm{ML}$ & ML & ML & $\mathrm{ML}$ & ML & $\mathrm{ML}$ & CEBP \\
\hline & 95 & $416 B$ & $421 A$ & $421 B$ & 427 & 429B & 53 \\
\hline Quartzo & 10 & 5 & 7 & 7 & 10 & 7 & 7 \\
\hline K-feldspato & 5 & $-\cdots$ & $-\cdots$ & 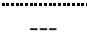 & --- & --- & 5 \\
\hline Plagioclásio & 55 & 35 & 35 & 31 & 45 & 43 & 50 \\
\hline Biotita & 30 & 23 & 25 & 30 & 18 & 22 & 25 \\
\hline Anfibólio & -- & 22 & 30 & 31 & 25 & 23 & -- \\
\hline Titanita & --- & 4 & --- & 1 & - & 2 & 10 \\
\hline Epídoto & --- & 10 & --- & --- & 2 & --- & --- \\
\hline Allanita & --- & --- & -- & -- & --- & --- & 1 \\
\hline Opacos & -- & 1 & 3 & -- & -- & 3 & 2 \\
\hline Acessórios & $\mathrm{Tr}$ & $\mathrm{Tr}$ & $\mathrm{Tr}$ & $\mathrm{Tr}$ & $\mathrm{Tr}$ & $\mathrm{Tr}$ & Tr \\
\hline Q & 14,3 & 12,5 & 16,7 & 18,4 & 18,2 & 14,0 & 11,3 \\
\hline A & 7,1 & 0,0 & 0,0 & 0,0 & 0,0 & 0,0 & 8,1 \\
\hline $\mathbf{P}$ & 78,6 & 87,5 & 83,3 & 81,6 & 81,8 & 86,0 & 80,6 \\
\hline$M$ & 30,0 & 60,0 & 58,0 & 62,0 & 45,0 & 50,0 & 38,0 \\
\hline
\end{tabular}

Obs. Os acessórios são: zircão, apatita, mica branca e carbonato.

tipo patchy zoning (Fig. 7B); e iii) cristais maiores, fenocristais/xenocristais, com tamanho da ordem de 2-3 mm, sempre com zonação (normal e inversa) e comumente mostrando bordas de reação/ absorção com a matriz fina da rocha diorítica (Fig. 7C). Em ambos os casos estes plagioclásios devem ter composição pelo menos no campo do oligoclásio cálcio ( $\mathrm{An}>20 \%$ ), haja vista seus processos de alteração secundária (saussuritização e/ou carbonatação) e sua forte zonação.

0 quartzo ocorre essencialmente como pequenos cristais $(\leq 1 \mathrm{~mm})$, xenomórficos e límpidos, sempre com extinção ondulante e/ou fraturados. 0 K-feldspato, quando presente, ocorre como pequenos cristais $(<1 \mathrm{~mm})$, xeno-hipidiomórficos, com as maclas polissintéticas (albita-periclina) em padrão tartan, com textura pertítica e extinção ondulante.

Biotita e anfibólio são os máficos essenciais ( $\Sigma \mathrm{M}=25-62 \%)$. 0 primeiro ocorre como cristais lamelares de coloração amarela esverdeada, fortemente pleocróico em tons castanho a avermelhado, usualmente de contatos serrilhados a retos com os demais minerais, podendo apresentar planos de clivagens deformados/levemente dobrados e extinção ondulante, e ainda incipientes processos de alteração para clorita e/ou oxidação. 0 anfibólio, hornblenda, aparece como pequenos cristais xeno-hipidiomórficos de cor verde e com pleocroísmo em tons de verde amarelado a verde azulado, tanto em seções longitudinais quanto basais com as clivagens em $60^{\circ}-120^{\circ}$ (Fig. 7D).

Titanita, epídoto e minerais opacos, ambos no geral, ocorrem como pequenos cristais idio-hipidiomórficos $(<0,5 \mathrm{~mm})$, este último podendo ocorrer ainda com finas e irregulares coroas de titanita. Todos são acessórios. Raros e diminutos cristais $(<0,2 \mathrm{~mm})$, no geral idiomórficos, de allanita, zircão e apatita são também observados.

\subsubsection{Química Mineral}

Em uma amostra (ML-55) da fácies granodiorítica/tonalítica foram obtidas quatro análises pontuais de biotita, em diferentes cristais, todas as análises sempre nas porções mais centrais dos cristais. Em anfibólio obteve-se quatro análises em dois cristais (borda $\rightarrow$ centro de cada um). Cinco análises foram obtidas em titanita (centro e borda de um cristal; três análises pontuais em diferentes cristais). Três análises compondo um perfil de um plagioclásio e cinco análises em um perfil de um fenocristal de K-feldspato. Nas fórmulas estruturais calculadas para as diferentes fases minerais foram utilizadas as seguintes bases de oxigênios: 22 para biotita, 23 para anfibólio, 5 para titanita, e 

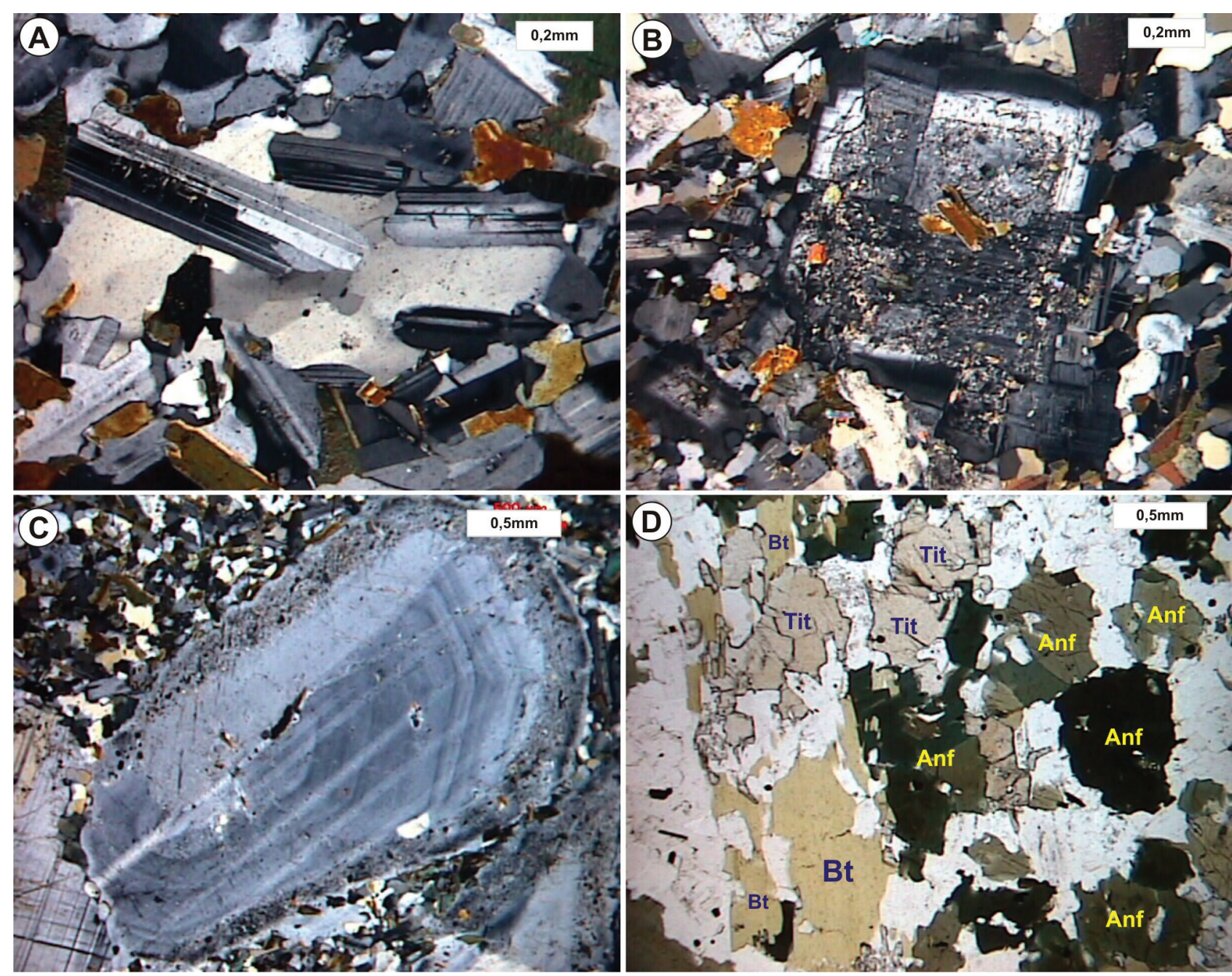

Figura 7. Minerais da fácies diorítica. A) Cristais idiomórficos alongados de plagioclásio da matriz; B) Cristais de plagioclásio zonados compondo textura synneusis; C) Xenocristal de plagioclásio com zonação oscilatória e borda de reação/absorção com a matriz diorítica; D) Assembleia máfica dominante com cristais de biotita (Bt), anfibólio (Anf) e titanita (Tit), mostrando discreta orientação.

Figure 7. Mineral of dioritic facies. A) Idiomorfic elongated crystals of plagioclase in matrix; B) Zoned plagioclase crystals with synneusis texture; C) Xenocristal plagioclase with oscillatory zonation and edge reaction/absorption with dioritic matrix; D) Dominant mafic with biotite crystals (Bt), amphibole (Anf) and titanite (Tit), showing discrete orientation.

32 para plagioclásio e para K-feldspato (Tabs. 3 e 4).

\section{Biotita}

Nos cristais de biotita analisados a somatória do sítio octaédrico $(\mathrm{Y})$ é $\geq 5,5$. As análises mostram homogeneidade composicional com $\mathrm{FeO}$ $\approx 21 \%, \mathrm{MgO} \approx 10-11 \%$ e $\mathrm{Al}_{2} \mathrm{O}_{3} \approx 14 \%$, o que acarreta em razões $\mathrm{Fe} / \mathrm{Mg}$ também homogêneas $[\mathrm{Fe} /$ $(\mathrm{Fe}+\mathrm{Mg})=0,5]$. Composicionalmente são intermediárias entre os polos "flogopita-annita" (Fig. 8A) com valores de $\mathrm{Al}^{\mathrm{IV}}$ em 2,2 (Tab. 3). Em diagramas que utilizam composição de biotita para definir séries/associações magmáticas (Abdel-Rahman, 1994), as análises se dispõem no campo dos granitos de natureza cálcio-alcalina, orogênicos, de afinidade com os granitos tipos-I (Figs. 8B, C e D).

\section{Anfibólio}

Os dois cristais analisados (borda e centro de cada um) têm ( $\mathrm{Ca}+\mathrm{Na}) \mathrm{B} \geq 1,0$, e $\mathrm{Na}_{\mathrm{B}}<0,5$, o que identifica como anfibólios cálcicos (Leake et al., 1997); mostram composições relativamente homogênea quanto aos teores de FeOt (19\%), MgO (9\%) e $\mathrm{Al}_{2} \mathrm{O}_{3}$ (8\%), evidenciando ausência de zonação nos mesmos. Estes valores implicam em razões $\mathrm{Mg} /\left(\mathrm{Mg}+\mathrm{Fe}^{2+}\right)$ homogêneas e maiores do que 0,5 , com $S_{\text {ipfu }}>6,5$, com composições no campo das edenitas (Fig. 9 e Tab. 3). Estes dados analíticos indicam pelo geobarômetro de alumínio em hornblenda (Schmidt, 1992) pressão de cristalização da ordem de 4 kbar, e temperatura da ordem de $750^{\circ} \mathrm{C}$ pelo geotermômetro de Blundy \& Holland (1990). 


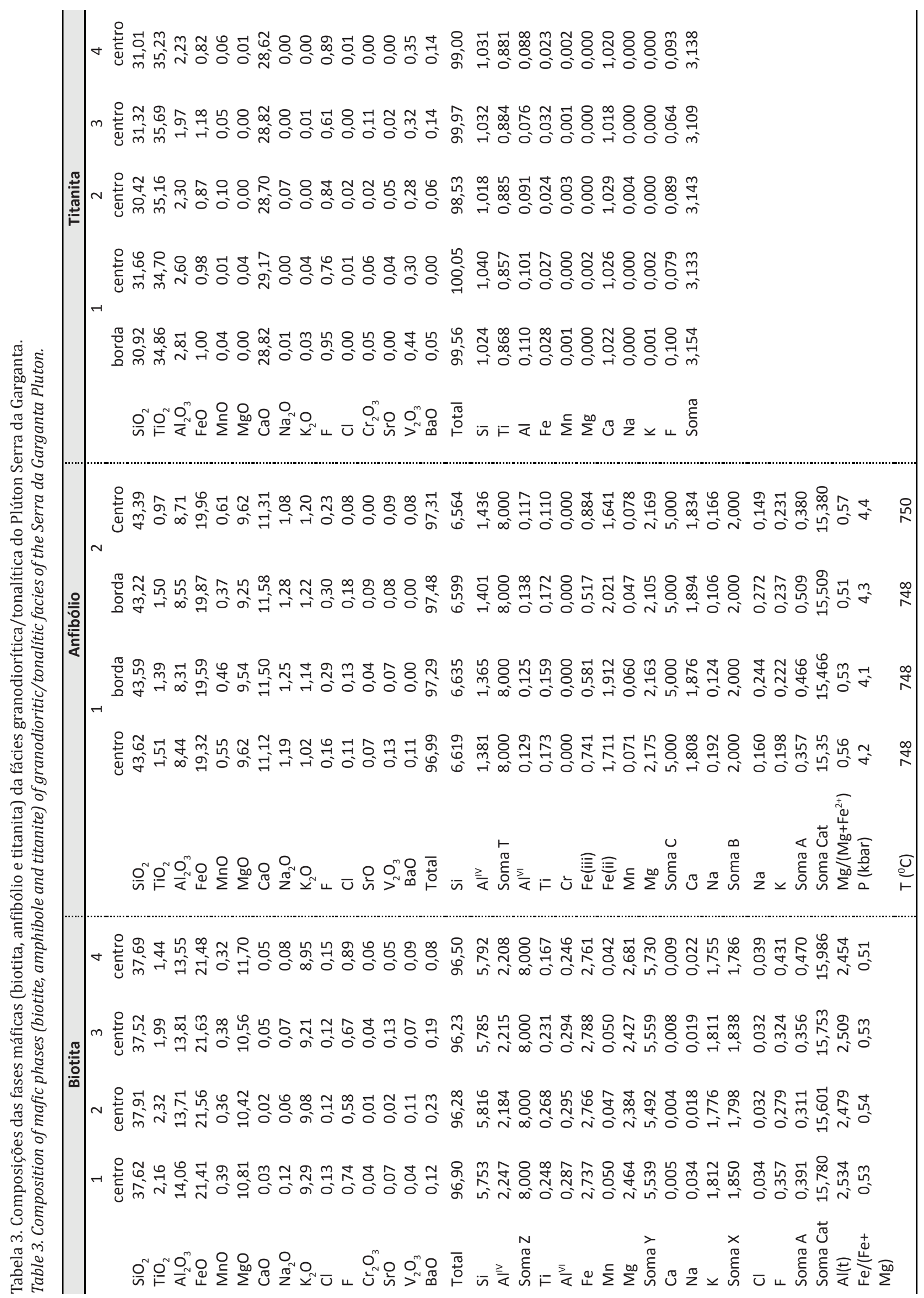




\section{Titanita}

Os quatro cristais analisados mostram-se homogêneos com $\mathrm{TiO}_{2} \approx 35 \%, \mathrm{CaO} \approx 29 \%$, e com valores baixos de alumínio $\mathrm{Al}_{2} \mathrm{O}_{3}=1,97-2,81 \%$, mas dentro da faixa de titanitas magmáticas, bem distintos daqueles de titanitas secundárias que no geral são maiores do que 6\% (Tulloch, 1979). Da mesma forma, os teores de flúor e de $\mathrm{Al}^{(\mathrm{t})}+\mathrm{Fe}^{3+}$ são baixos e corroborando com os valores para titanitas magmáticas (Enami et al., 1993) (Fig. 10 e tab. $3)$.

\section{Feldspatos}

O cristal de plagioclásio analisado (um perfil com três pontos analíticos) mostra-se muito homogêneo com $\mathrm{Na}_{2} \mathrm{O}$ entre 8,5-8,9\%, $\mathrm{CaO}$ entre 4,8-5,2\% e $\mathrm{K}_{2} \mathrm{O} \leq 0,2$, o que acarreta composições de oligoclásio cálcico com An25-23\%. Da mesma forma, o K-feldspato, apesar do perfil com cinco pontos analíticos (Tab. 4), também mostra grande homogeneidade composicional, com teores de $\mathrm{K}_{2} \mathrm{O}$ em $15 \%$ e de $\mathrm{Na}_{2} \mathrm{O}$ em $0,6 \%$, o que implica em teores de Or $\approx 94 \%$.

Tabela 4. Composições dos feldspatos da fácies granodiorítica/tonalítica do Plúton Serra da Garganta. Table 4. Composition of feldspar of granodioritic/tonalitic facies of the Serra da Garganta Pluton.

\begin{tabular}{|c|c|c|c|c|c|c|c|c|}
\hline & \multicolumn{5}{|c|}{ K-Feldspato } & \multicolumn{3}{|c|}{ Plagioclásio } \\
\hline & \multicolumn{5}{|c|}{ Cristal 1} & \multicolumn{3}{|c|}{ Cristal 1} \\
\hline & B & $\mathrm{B} / \mathrm{C}-1$ & $B / C-2$ & $B / C-3$ & C & B & $\mathrm{B} / \mathrm{C}-1$ & $B / C-2$ \\
\hline $\mathrm{SiO}_{2}$ & 63,48 & 64,84 & 65,10 & 63,14 & 67,19 & 60,92 & 61,62 & 62,98 \\
\hline $\mathrm{Al}_{2} \mathrm{O}_{3}$ & 15,41 & 15,37 & 15,78 & 15,19 & 15,73 & 20,44 & 20,04 & 19,65 \\
\hline $\mathrm{FeO}$ & 0,07 & 0,03 & 0,06 & 0,13 & 0,08 & 0,11 & 0,06 & 0,03 \\
\hline $\mathrm{CaO}$ & 0,00 & 0,02 & 0,00 & 0,00 & 0,00 & 5,21 & 5,25 & 4,84 \\
\hline $\mathrm{Na}_{2} \mathrm{O}$ & 0,67 & 0,65 & 0,65 & 0,68 & 0,67 & 8,50 & 8,87 & 8,77 \\
\hline $\mathrm{K}_{2} \mathrm{O}$ & 15,13 & 15,14 & 15,37 & 15,78 & 15,66 & 0,21 & 0,20 & 0,10 \\
\hline $\mathrm{BaO}$ & 0,37 & 0,53 & 0,16 & 0,09 & 0,29 & 0,03 & 0,00 & 0,02 \\
\hline Total & 95,13 & 96,57 & 97,12 & 95,02 & 99,61 & 95,42 & 96,03 & 96,39 \\
\hline $\mathrm{Si}$ & 12,334 & 12,396 & 12,353 & 12,320 & 12,428 & 11,332 & 11,395 & 11,551 \\
\hline $\mathrm{Al}$ & 3,529 & 3,463 & 3,528 & 3,493 & 3,429 & 4,480 & 4,366 & 4,246 \\
\hline $\mathrm{Fe}^{2+}$ & 0,012 & 0,004 & 0,010 & 0,020 & 0,012 & 0,017 & 0,009 & 0,004 \\
\hline $\mathrm{Ca}$ & 0,000 & 0,004 & 0,000 & 0,001 & 0,000 & 1,038 & 1,040 & 0,952 \\
\hline $\mathrm{Na}$ & 0,251 & 0,241 & 0,239 & 0,258 & 0,241 & 3,067 & 3,179 & 3,119 \\
\hline $\mathrm{K}$ & 3,749 & 3,693 & 3,720 & 3,927 & 3,694 & 0,050 & 0,046 & 0,023 \\
\hline $\mathrm{Ba}$ & 0,028 & 0,040 & 0,012 & 0,007 & 0,021 & 0,002 & 0,000 & 0,002 \\
\hline Total & 19,903 & 19,841 & 19,862 & 20,026 & 19,825 & 19,986 & 20,035 & 19,897 \\
\hline An & 0,00 & 0,10 & 0,00 & 0,00 & 0,00 & 25,00 & 24,40 & 23,20 \\
\hline$A b$ & 6,30 & 6,10 & 6,00 & 6,20 & 6,10 & 73,80 & 74,50 & 76,20 \\
\hline Or & 93,70 & 93,80 & 94,00 & 93,80 & 93,90 & 1,20 & 1,10 & 0,60 \\
\hline
\end{tabular}

Obs: B (borda), C (Centro), B/C (Borda-Centro) 

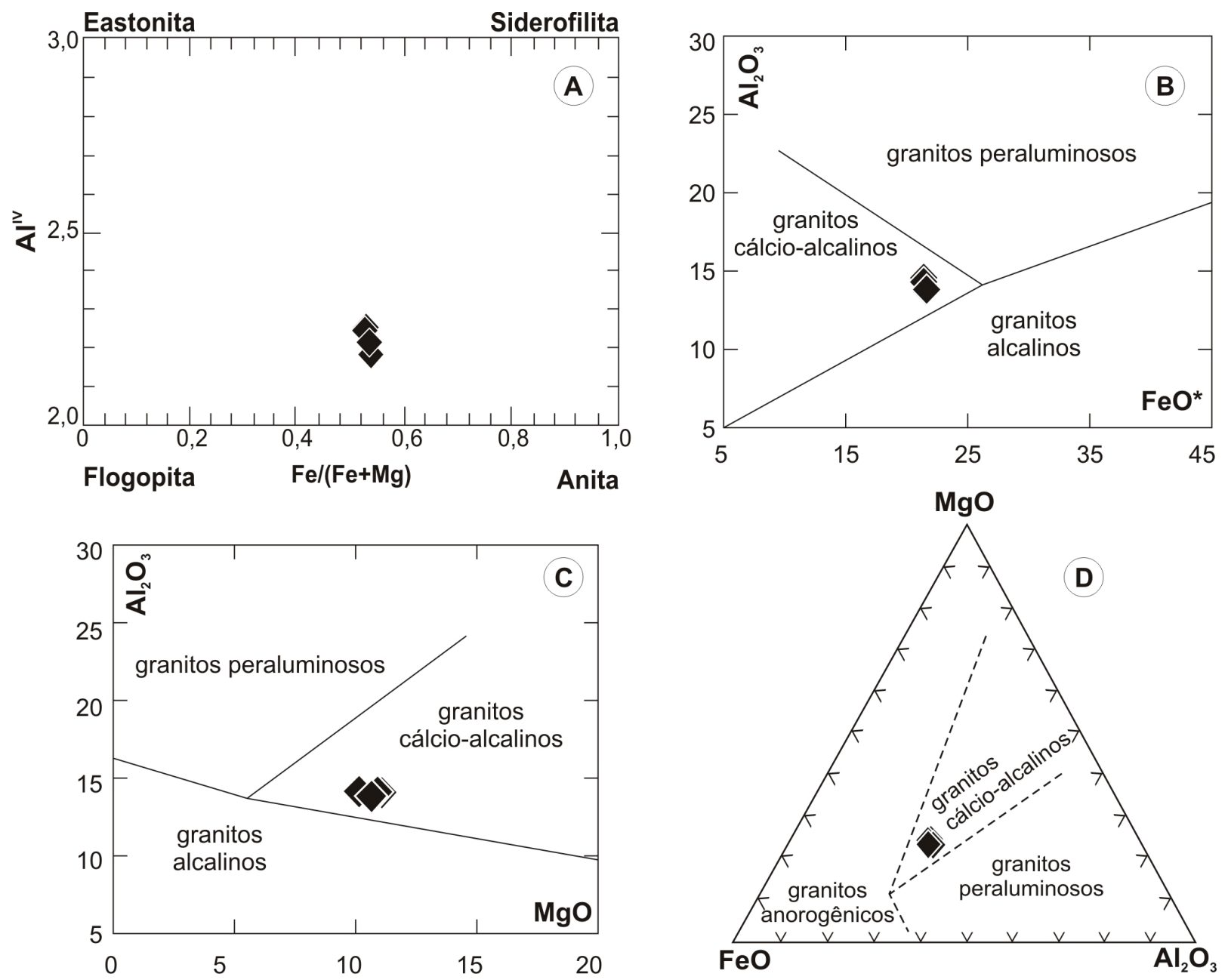

Figura 8. Diagramas para as biotitas analisadas. A) Quadrilátero composicional de Deer et al. (2013); B, C, D) Diagramas de Abdel-Rahman (1994).

Figure 8. Diagrams for biotite analyzed. A) Quadrilateral compositional of Deer et al. (2013); B, C, D) Abdel-Rahman Diagrams (1994).

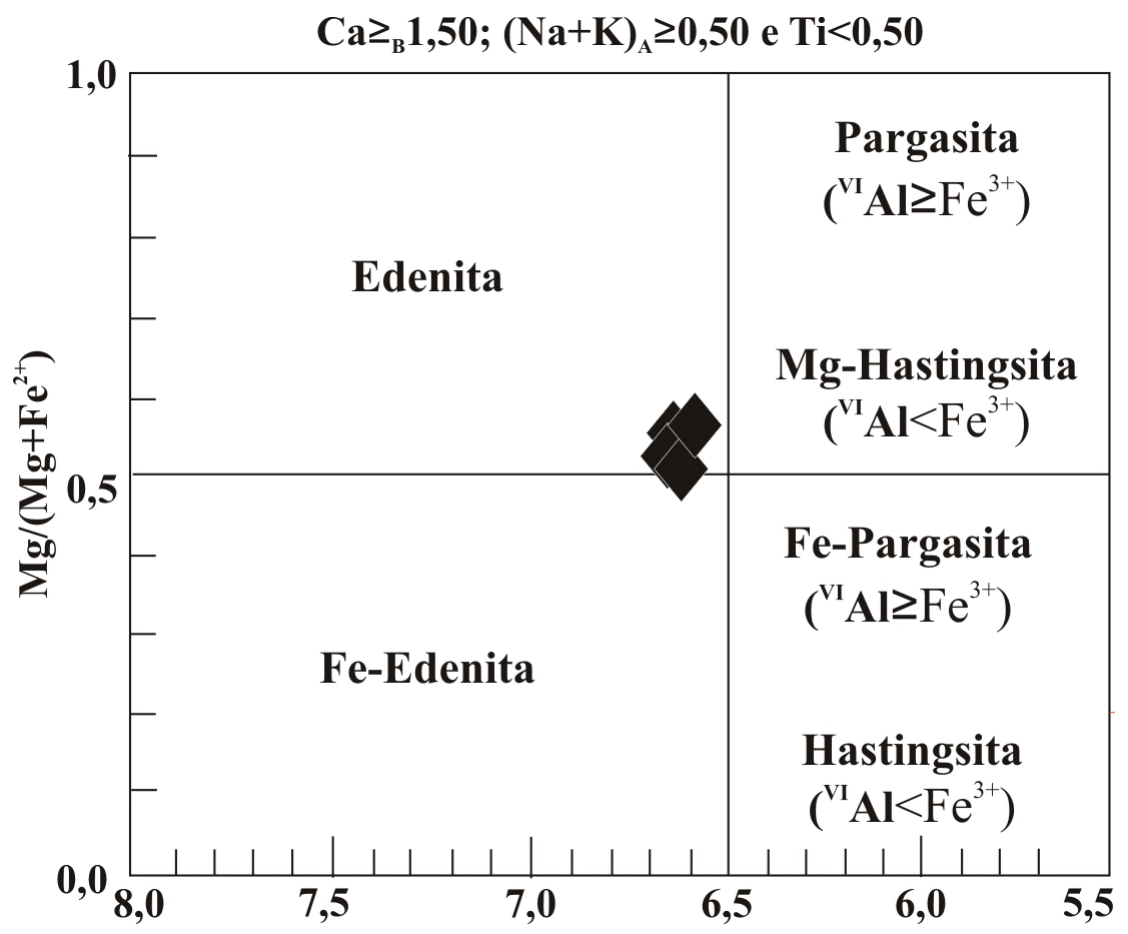

Figura 9. Diagrama de Leake et al. (1997) para os anfibólios estudados.

Figure 9. Leake et al. (1997) Diagram for amphiboles studied. 


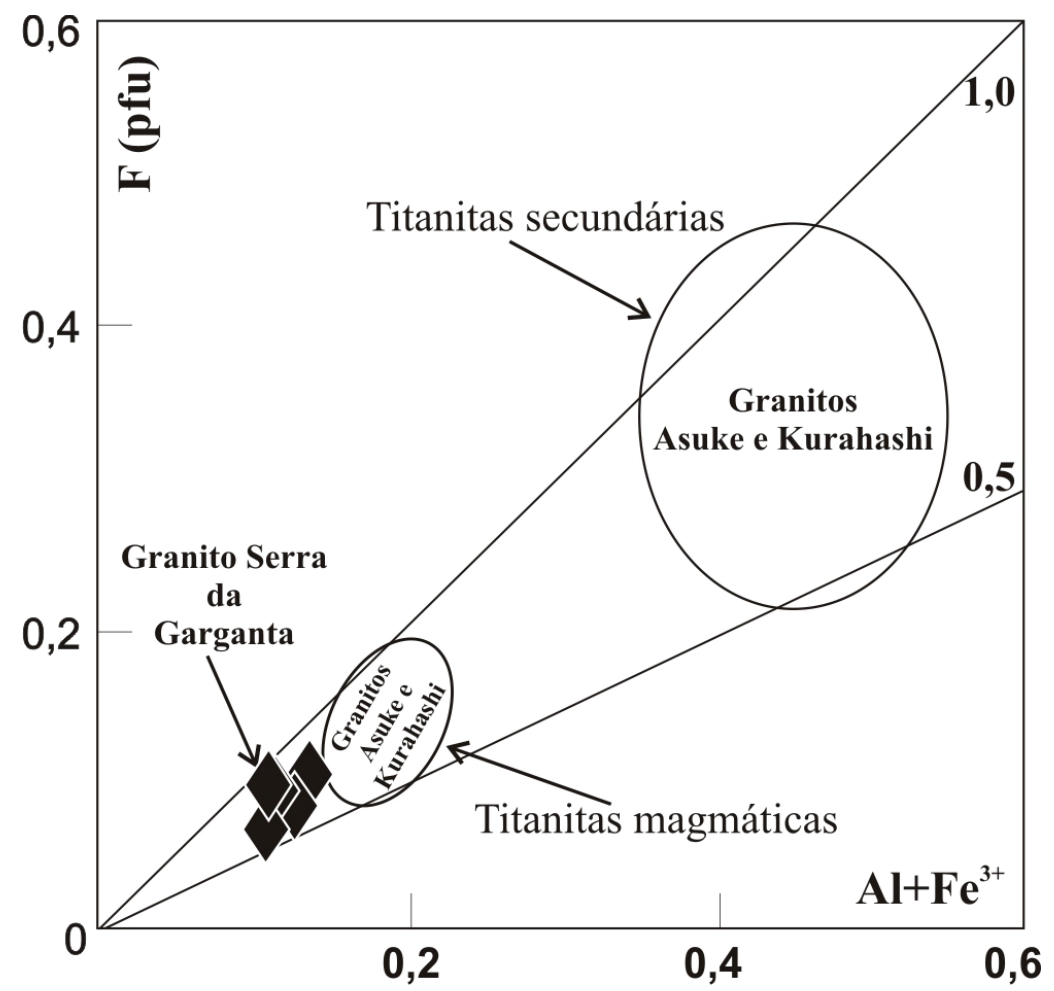

Figura 10. Diagrama $\mathrm{F}$ versus $\mathrm{Al}^{+} \mathrm{Fe}^{3+}$ com os campos para titanitas primárias e secundárias estudadas por Enami et al. (1993). Figure 10. F versus $\mathrm{Al}^{+} \mathrm{Fe}^{3+}$ Diagram with fields for primary and secondary titanites studied by Enami et al. (1993).

\subsubsection{Litoquímica}

\section{Elementos Maiores, Menores e Traços}

Os resultados para elementos maiores, alguns elementos traços e parâmetros químicos estão distribuídos na tabela 5 .

Nos diagramas de Harker, considerando SiO2 como índice de diferenciação, é possível identificar comportamento dos elementos químicos ao longo da evolução magmática e a clara relação entre as fácies do Plúton Serra da Garganta (Figs. 11 e 12). As amostras são de natureza ácida $\left(\mathrm{SiO}_{2}\right.$ $>63 \%)$, exceto as da fácies diorítica $\left(\mathrm{SiO}_{2}=54,00\right.$ - 58,86\%), além de três rochas menos evoluídas da fácies granodiorítica/tonalítica $\left(\mathrm{SiO}_{2}=60,50\right.$ $62,52 \%$ ), todas consideradas intermediárias.

As rochas da fácies diorítica são as que apresentam os mais altos teores em $\mathrm{Fe}_{2} \mathrm{O}_{3 \mathrm{t}^{\prime}} \mathrm{MgO}$, $\mathrm{CaO}, \mathrm{TiO}_{2}, \mathrm{P}_{2} \mathrm{O}_{5} \mathrm{eV}$, quando comparadas as da fácies granodiorítica/tonalítica (Fig. 11). Porém ambas as fácies mostram correlações negativas de $\mathrm{Fe}_{2} \mathrm{O}_{3 \mathrm{t}}$ e $\mathrm{MgO}$ com $\mathrm{SiO}_{2}$ que são explicadas pelo fracionamento de biotita, anfibólio e minerais opacos, de $\mathrm{CaO}$ relacionado ao fracionamento de plagioclásio e titanita, de $\mathrm{TiO}_{2}$ ligada ao fracionamento de titanita e minerais opacos e por fim $\mathrm{P}_{2} \mathrm{O}_{5}$ favorecendo o fracionamento de apatita. No $\mathrm{Al}_{2} \mathrm{O}_{3}$ percebe-se com mais clareza, uma evolução com inclinação positiva para a fácies diorítica e aos $60 \%$ de $\mathrm{SiO}_{2}$ tal inclinação passa para negativa no caso das rochas da fácies granodiorítica/tonalítica. $\mathrm{Na}_{2} \mathrm{O}$ e $\mathrm{K}_{2} \mathrm{O}$ não possuem tendências claras, ainda que seja sugestivo uma leve tendência positiva para as amostras da fácies diorítica (até $60 \%$ de $\mathrm{SiO}_{2}$ ) e negativa para as amostras da fácies granodiorítica/tonalítica, situação similar ao $\mathrm{Al}_{2} \mathrm{O}_{3}$ e no caso do $\mathrm{K}_{2} \mathrm{O}$ uma ligeira tendência a correlação positiva para as duas fácies. Todos os diagramas sugerem cogeneticidade entre as amostras das duas fácies.

Com os diagramas para elementos traços (Fig. 12) é possível verificar que a fácies diorítica mostra uma maior dispersão dos diferentes elementos quando comparado com a fácies granodiorítica/tonalítica; contudo ambas mostrando correlação negativa para Sr, V e Y, associado ao fracionamento de minerais máficos ricos em $\mathrm{CaO}(\mathrm{Sr})$ e $\mathrm{Fe}_{2} \mathrm{O}_{3 \mathrm{t}}(\mathrm{V}, \mathrm{Y})$, como anfibólios, titanita e minerais opacos quando presentes na composição modal. Apesar de relativa dispersão, os diagramas para $\mathrm{Rb}$ e $\mathrm{Ba}$, e em menor grau $\mathrm{Zr}$ e $\mathrm{Nb}$, mostram situação similar ao observado para $\mathrm{Na}_{2} \mathrm{O}$ e $\mathrm{Al}_{2} \mathrm{O}_{3}$, tendência positiva até $60 \%{\mathrm{de} \mathrm{SiO}_{2}}_{2}$ e depois negativa. O Ni mostra forte dispersão. 


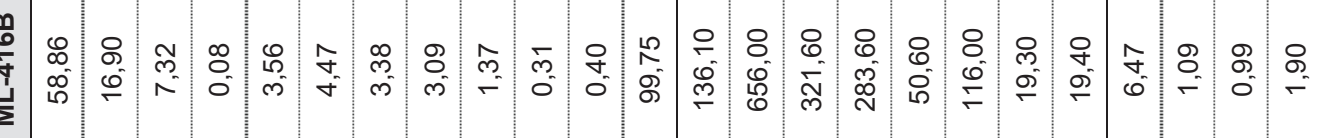

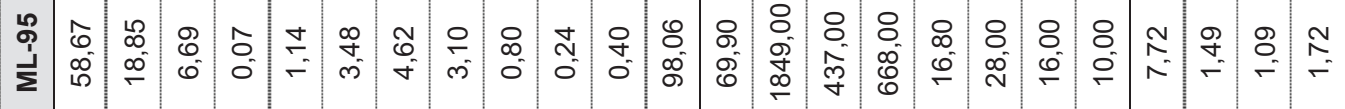

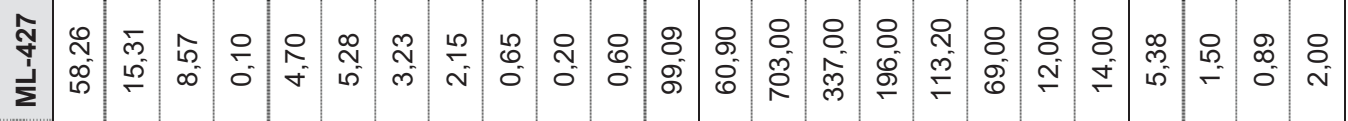

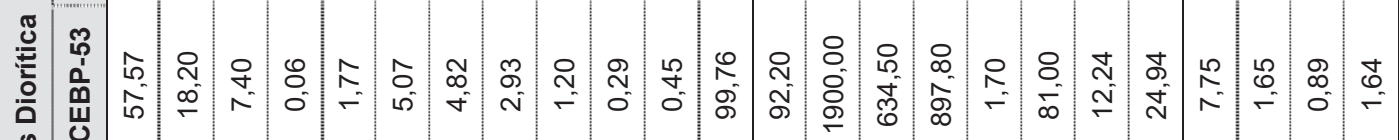

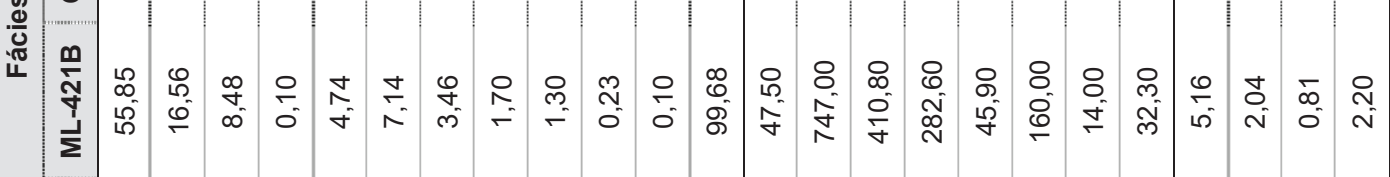

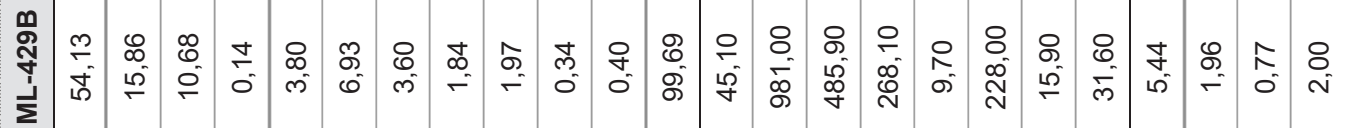

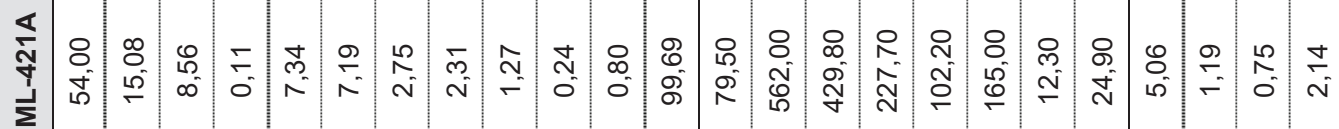

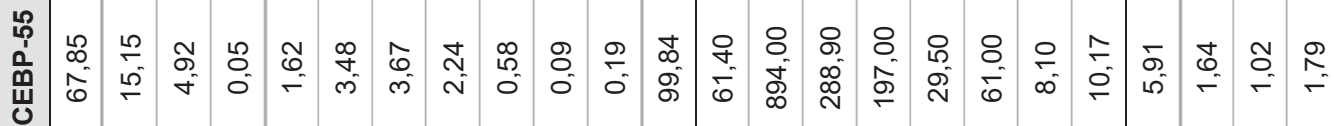

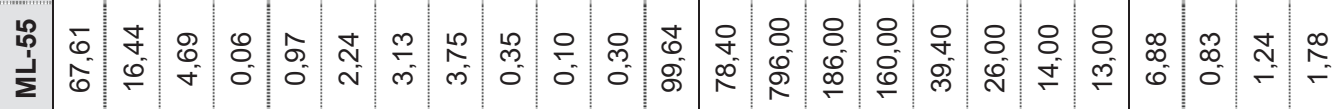

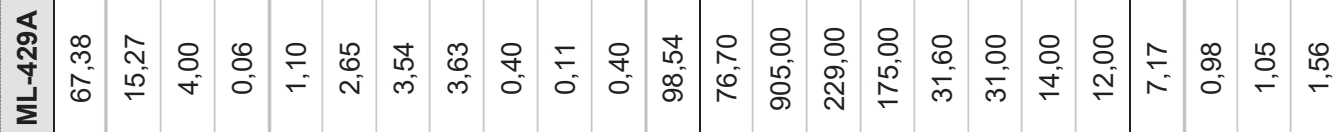

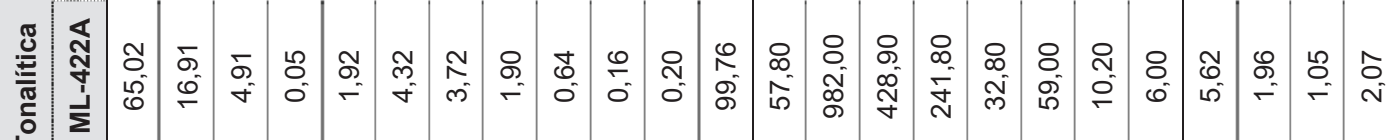

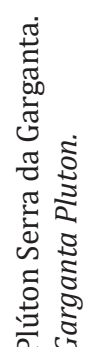

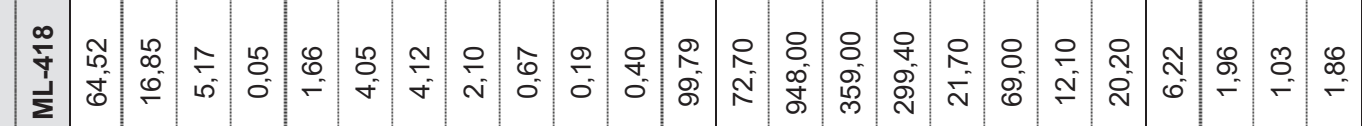

융

帘

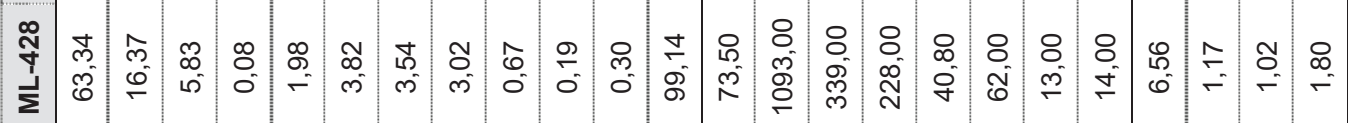

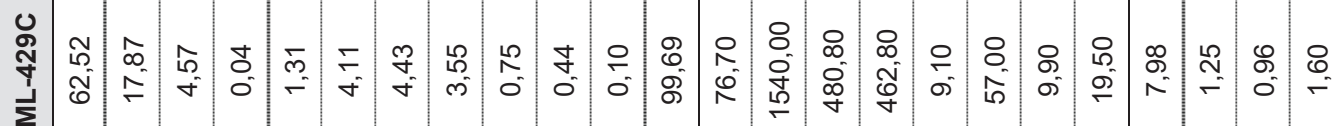

茎造

莺

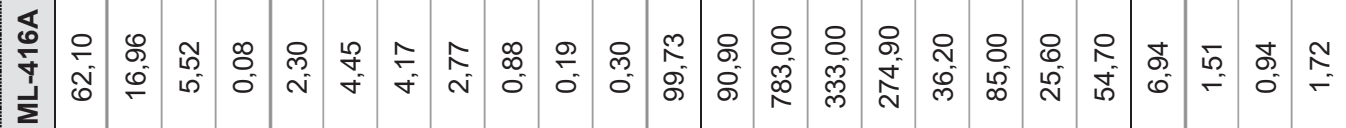

खाँ है

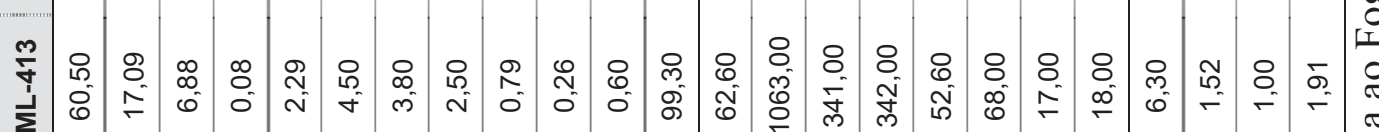

要

is

$\frac{\pi}{8} \frac{8}{8}$

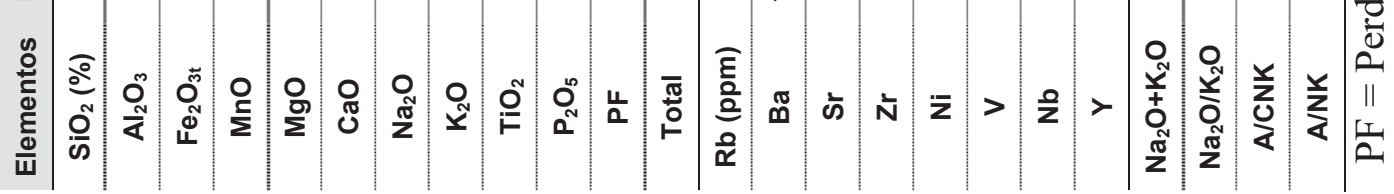



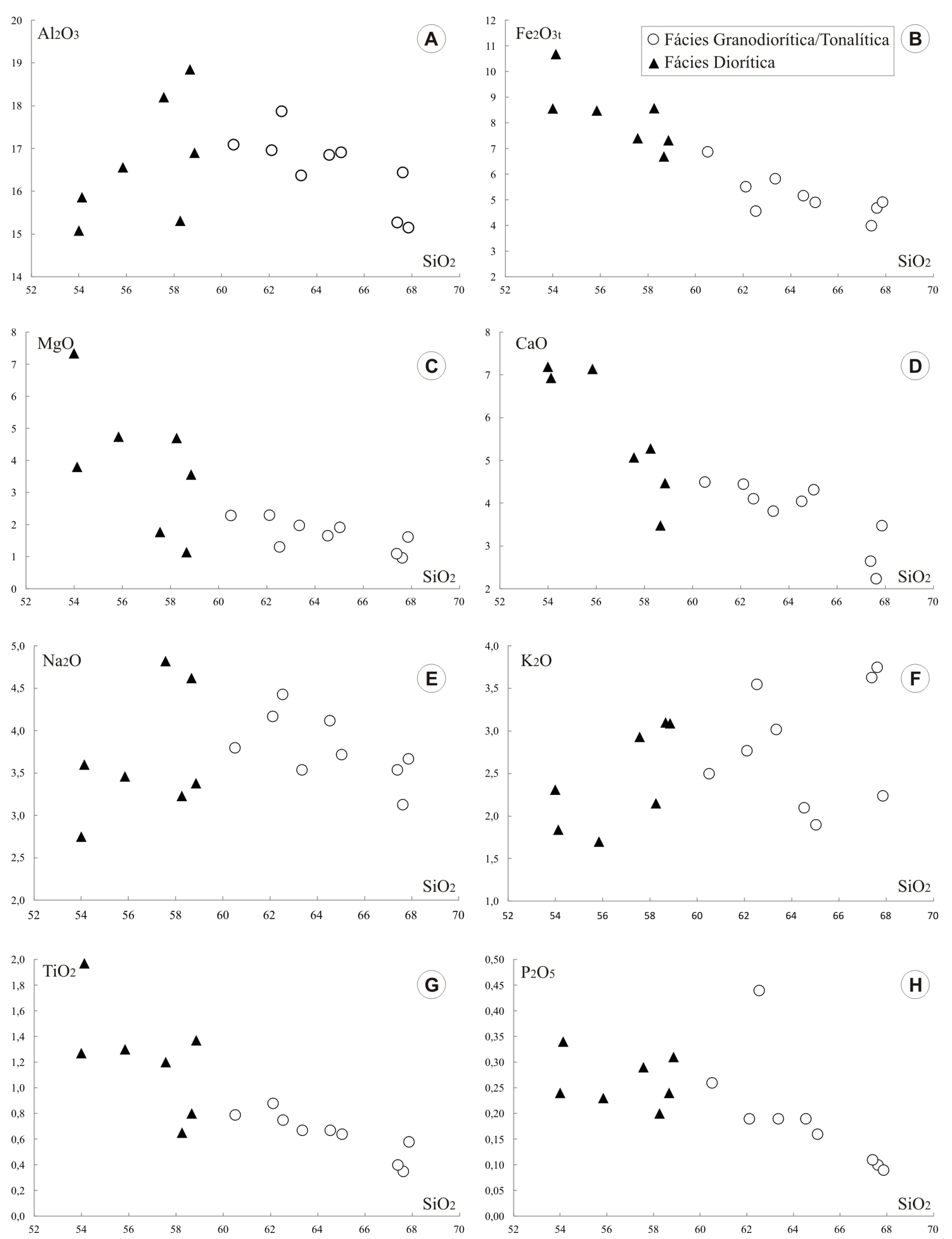

Figura 11. Diagramas tipo Harker para elementos maiores. A) $\mathrm{Al}_{2} \mathrm{O}_{3}$; B) $\mathrm{Fe}_{2} \mathrm{O}_{3} \mathrm{t}$; C) $\mathrm{MgO}$; D) CaO; E) $\mathrm{Na}_{2} \mathrm{O}$; F) $\mathrm{K}_{2} \mathrm{O}$; G) $\mathrm{TiO}_{2}$; H) $\mathrm{P}_{2} \mathrm{O}_{5}$. Figure 11. Diagrams of type Harker for major elements. A) $\left.\left.\mathrm{Al}_{2} \mathrm{O}_{3} ; \mathrm{B}\right) \mathrm{Fe}_{2} \mathrm{O}_{3} \mathrm{t} ; \mathrm{C}\right) \mathrm{MgO}$; D) $\mathrm{CaO}$; E) $\mathrm{Na}_{2} \mathrm{O}$; F) $\mathrm{K}_{2} \mathrm{O}$; G) $\left.\mathrm{TiO}_{2} ; \mathrm{H}\right) \mathrm{P}_{2} \mathrm{O}_{5}$ 

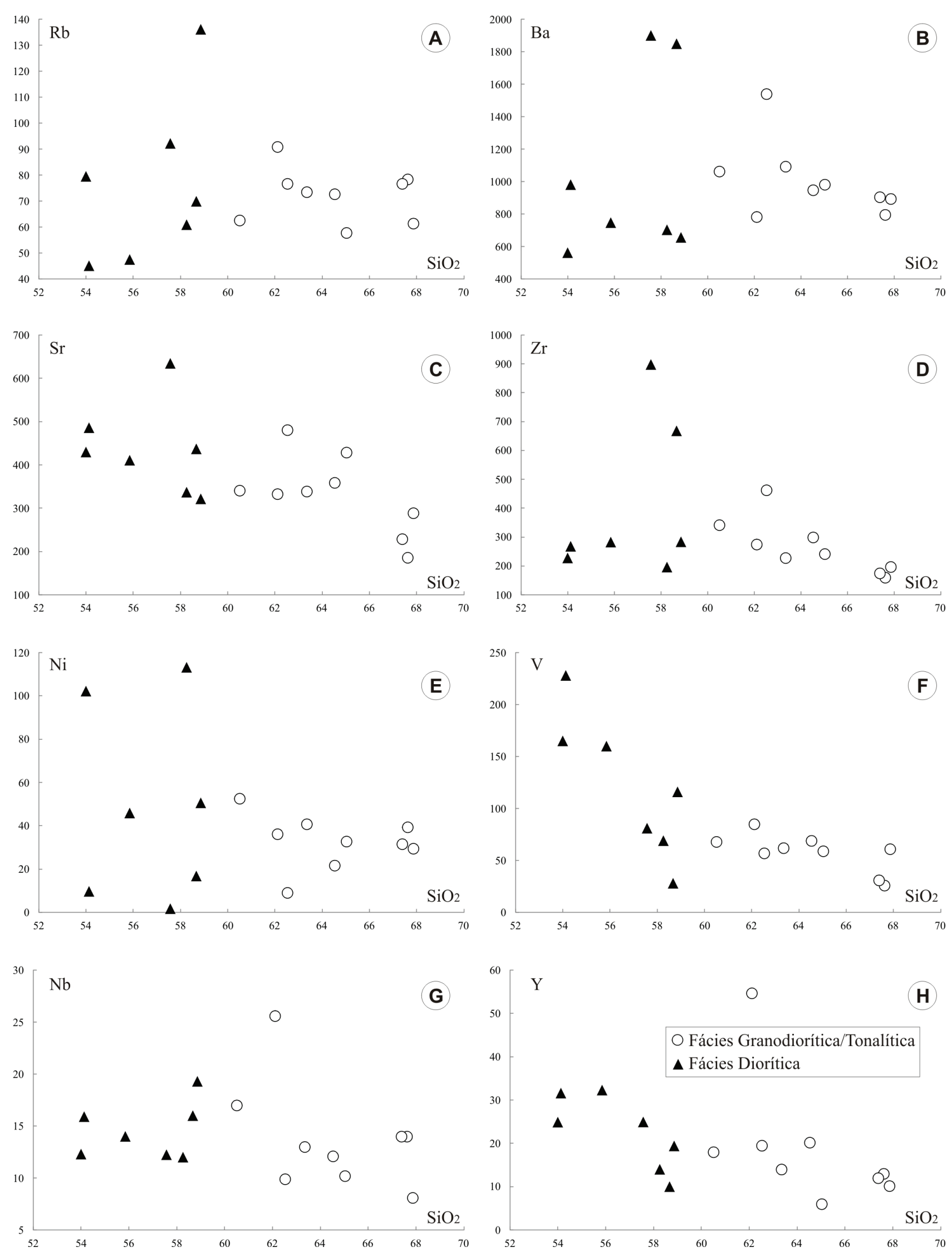

Figura 12. Diagramas tipo Harker para elementos traços. A) Rb; B) Ba; C) Sr; D) Zr; E) Ni; F) V; G) Nb; H) Y. Figure 12. Diagrams type Harker for trace elements. A) $R b ; B) B a$;) $\mathrm{Sr}$; D) $\mathrm{Zr}$; E) Ni; F) $\mathrm{V}$; G) $\mathrm{Nb}$; H) $\mathrm{Y}$. 


\section{Saturação em Alumina}

A utilização do índice de saturação em alumina (Fig. 13), em sua forma adaptada por Maniar \& Piccoli (1989), mostra que as rochas do Plúton Serra da Garganta são transicionais de metaluminosas a peraluminosas em sua fácies granodiorítica/tonalítica, predominando as peraluminosas, enquanto que a fácies diorítica é claramente metaluminosa, com apenas uma amostra caindo no campo do peraluminoso. Este caráter peraluminoso é creditado à pequena quantidade de $\mathrm{CaO}$, e não, necessariamente, ao excesso em $\mathrm{Al}_{2} \mathrm{O}_{3}$.

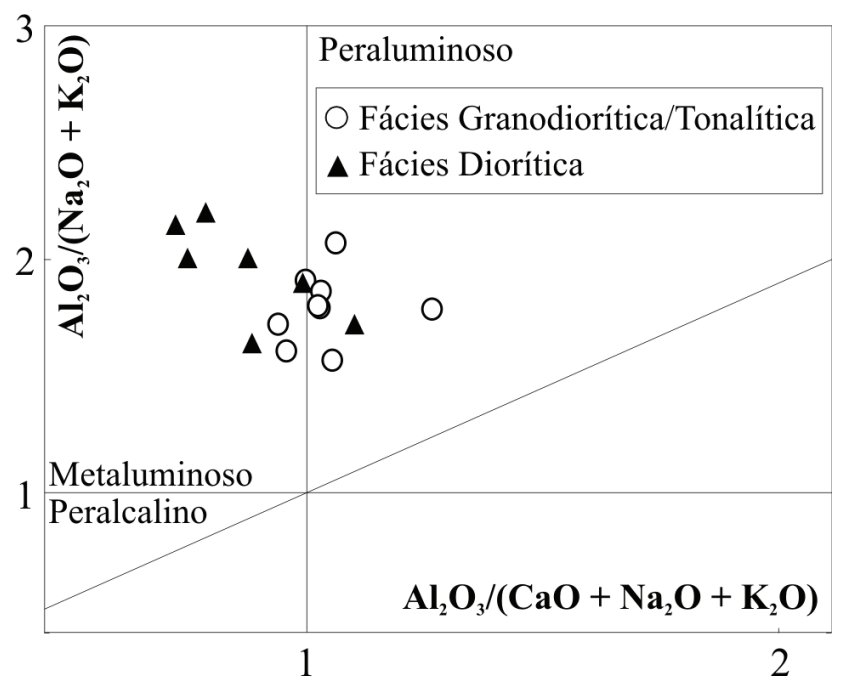

Figura 13. Representação das diferentes fácies do Plúton Serra da Garganta, segundo o índice de Shand (Maniar \& Piccoli, 1989).

Figure 13. Representation of the different facies of the Serra da Garganta Pluton, according to Shand index (Maniar \& Piccoli, 1989).

\section{Elementos Terras Raras}

As análises dos elementos terras raras estão distribuídas na tabela 6 e seus respectivos diagramas de ETR encontram-se na figura 14, com dados normalizados em relação ao condrito de

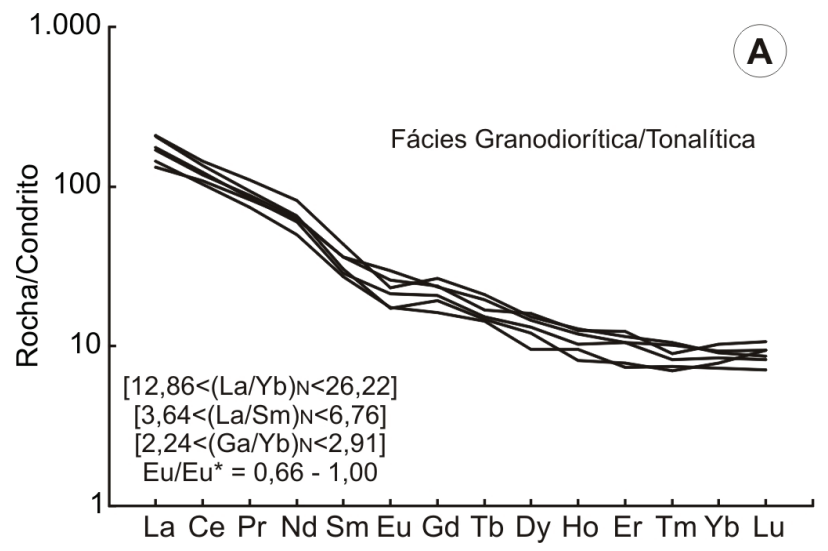

Evensen et al. (1978).

A partir da observação dos diagramas é possível identificar uma característica comum às duas fácies do Plúton Serra da Garganta, que é um enriquecimento relativo em relação ao condrito (Fig. 14), com moderado grau de fracionamento dos elementos terras raras leves (ETL) em relação aos elementos terras raras pesados (ETRP), com LaN entre 116 e 152 para fácies diorítica e 114 e 210 para fácies granodiorítica/tonalítica. 0 enriquecimento em ETRL é mais pronunciado para rochas da fácies granodiorítica/tonalítica, onde se observa na razão (La/Yb)N valores entre 12,9 e 26,2 , enquanto que nas rochas da fácies diorítica a razão (La/Yb)N mostra valores entre 8,2 e 15,5. Os espectros de ETRP, apontados pela razão (Gd/Yb)N, são subhorizontais (com ligeira inclinação negativa) com valores entre 2,2 e 2,9 para fácies granodiorítica/tonalítica e 1,8 e 3,1 para fácies diorítica.

Com relação à anomalia de európio, observam-se anomalias negativas a ligeiramente positivas (apenas para duas amostras da fácies diorítica, fig. 14). Para rochas da fácies granodiorítica/tonalítica observa-se uma variação de $\mathrm{Eu} / \mathrm{Eu}^{*}$ entre 0,66 e 1,00, enquanto para rochas da fácies diorítica a razão Eu/Eu* é entre 0,82 e 1,08.

\section{Definição de Séries Magmáticas}

A caracterização da série magmática foi feita a partir de diagramas binários com a finalidade de definir a filiação magmática. As observações já mencionados em itens anteriores demonstram se tratar de duas fácies com afinidades químicas muito parecidas, corroborando com os dados petrográficos anteriormente caracterizados, porém

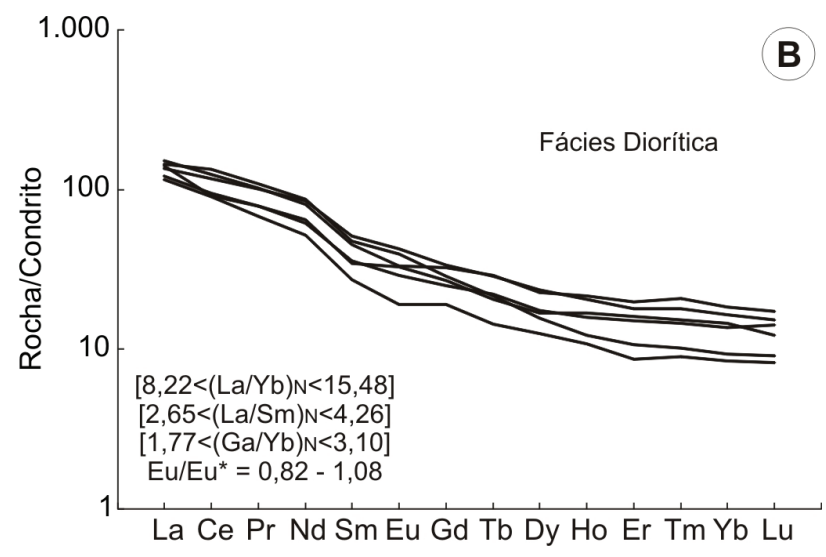

Figura 14. Diagramas de elementos terras raras (ETR) para as diferentes fácies do Plúton Serra da Garganta. A) Fácies granodiorítica/tonalítica; B) Fácies diorítica.

Figure 14. Diagrams of rare earth elements (REE) for the different facies of Serra da Garganta Pluton. A) Granodioritic/tonalitic facies; B) Dioritic facies. 
Tabela 6. Análises de elementos terras raras das rochas do Plúton Serra da Garganta. Table 6. Analysis of rare earth elements of the Serra da Garganta Pluton rocks.

\begin{tabular}{|c|c|c|c|c|c|c|c|c|c|c|c|c|}
\hline \multirow[b]{2}{*}{ Elementos } & \multicolumn{6}{|c|}{ Fácies Granodiorítica/Tonalítica } & \multicolumn{6}{|c|}{ Fácies Diorítica } \\
\hline & ML-413 & ML-429C & ML-428 & ML-418 & ML-429A & ML-55 & ML-421A & ML-429B & ML-421B & CEBP-53 & ML-427 & ML-416B \\
\hline $\mathrm{SiO}_{2}(\%)$ & 60,50 & 62,52 & 63,34 & 64,52 & 67,38 & 67,61 & 54,00 & 54,13 & 55,85 & 57,57 & 58,26 & 58,86 \\
\hline La (ppm) & 32,40 & 41,40 & 43,20 & 51,30 & 35,40 & 50,50 & 29,70 & 33,00 & 37,20 & 34,30 & 28,40 & 35,10 \\
\hline $\mathrm{Ce}$ & 69,60 & 75,10 & 78,00 & 92,40 & 66,30 & 86,30 & 60,30 & 74,10 & 78,90 & 58,10 & 57,30 & 84,90 \\
\hline Pr & 7,99 & 8,44 & 8,14 & 10,63 & 7,11 & 9,07 & 7,61 & 9,74 & 9,82 & 7,60 & 6,52 & 10,43 \\
\hline Nd & 29,50 & 30,30 & 28,30 & 38,70 & 23,50 & 30,90 & 29,20 & 40,00 & 38,30 & 30,50 & 24,40 & 41,00 \\
\hline Sm & 5,60 & 5,55 & 4,40 & 6,67 & 4,20 & 4,70 & 5,52 & 7,85 & 6,96 & 5,30 & 4,20 & 7,35 \\
\hline Eu & 1,51 & 1,73 & 1,24 & 1,34 & 1,01 & 1,00 & 1,68 & 2,47 & 1,92 & 1,91 & 1,10 & 2,28 \\
\hline Gd & 4,88 & 4,78 & 4,22 & 5,44 & 3,33 & 3,94 & 5,12 & 6,91 & 6,63 & 5,47 & 3,89 & 5,86 \\
\hline Tb & 0,63 & 0,73 & 0,57 & 0,79 & 0,54 & 0,55 & 0,83 & 1,07 & 1,09 & 0,77 & 0,54 & 0,81 \\
\hline Dy & 4,07 & 3,68 & 3,34 & 3,87 & 2,43 & 3,07 & 4,42 & 5,94 & 5,75 & 4,27 & 3,19 & 3,98 \\
\hline Ho & 0,71 & 0,68 & 0,58 & 0,73 & 0,54 & 0,46 & 0,90 & 1,16 & 1,22 & 0,95 & 0,61 & 0,69 \\
\hline $\mathrm{Er}$ & 2,05 & 1,75 & 1,75 & 1,92 & 1,22 & 1,30 & 2,50 & 2,97 & 3,28 & 2,67 & 1,43 & 1,77 \\
\hline $\mathrm{Tm}$ & 0,23 & 0,26 & 0,21 & 0,27 & 0,19 & 0,18 & 0,37 & 0,46 & 0,53 & 0,39 & 0,23 & 0,26 \\
\hline $\mathbf{Y b}$ & 1,70 & 1,53 & 1,40 & 1,51 & 1,20 & 1,30 & 2,25 & 2,71 & 3,02 & 2,40 & 1,40 & 1,53 \\
\hline Lu & 0,27 & 0,24 & 0,21 & 0,22 & 0,18 & 0,24 & 0,36 & 0,39 & 0,44 & 0,31 & 0,21 & 0,23 \\
\hline Total & 161,14 & 176,17 & 175,56 & 215,79 & 147,15 & 193,51 & 150,76 & 188,77 & 195,06 & 154,94 & 133,42 & 196,19 \\
\hline$(\mathrm{La} / \mathrm{Yb})_{\mathrm{N}}$ & 12,86 & 18,26 & 20,83 & 22,93 & 19,91 & 26,22 & 8,91 & 8,22 & 8,31 & 9,65 & 13,69 & 15,48 \\
\hline$(\mathrm{La} / \mathrm{Sm})_{\mathrm{N}}$ & 3,64 & 4,70 & 6,18 & 4,84 & 5,31 & 6,76 & 3,39 & 2,65 & 3,37 & 4,07 & 4,26 & 3,01 \\
\hline$(G d / Y b)_{N}$ & 2,32 & 2,52 & 2,44 & 2,91 & 2,24 & 2,45 & 1,84 & 2,06 & 1,77 & 1,84 & 2,25 & 3,10 \\
\hline Eu/Eu* & 0,86 & 1,00 & 0,87 & 0,66 & 0,80 & 0,69 & 0,95 & 1,00 & 0,85 & 1,08 & 0,82 & 1,03 \\
\hline
\end{tabular}

$\overline{\mathrm{Eu}} / \mathrm{Eu}^{*}=\left(\mathrm{Eu}_{\mathrm{N}} /\left[\left(\mathrm{Sm}_{\mathrm{N}}+\mathrm{Gd}_{\mathrm{N}}\right) / 2\right]\right.$.

uma menos (a diorítica) e outra mais (granodiorítica/tonalítica) evoluída.

No diagrama AFM (Fig. 15A) com a curva proposta por Irvine \& Baragar (1971) separando as séries toleítica e calcio-alcalina, fica claro a evolução cálcio-alcalina de rochas menos evoluídas (fácies diorítica) para mais evoluídas (fácies granodiorítica/tonalítica), o que é corroborado no diagrama de Jensen (modificado por Rickwood, 1989) com ambas as fácies evoluindo junto a série de rochas cálcio-alcalinas (Fig. 15B).

O Índice de Alcalinidade (Wright, 1969) (Fig. 16A) é útil para separar rochas cálcio-alcalinas, alcalinas e peralcalinas. Neste caso as rochas

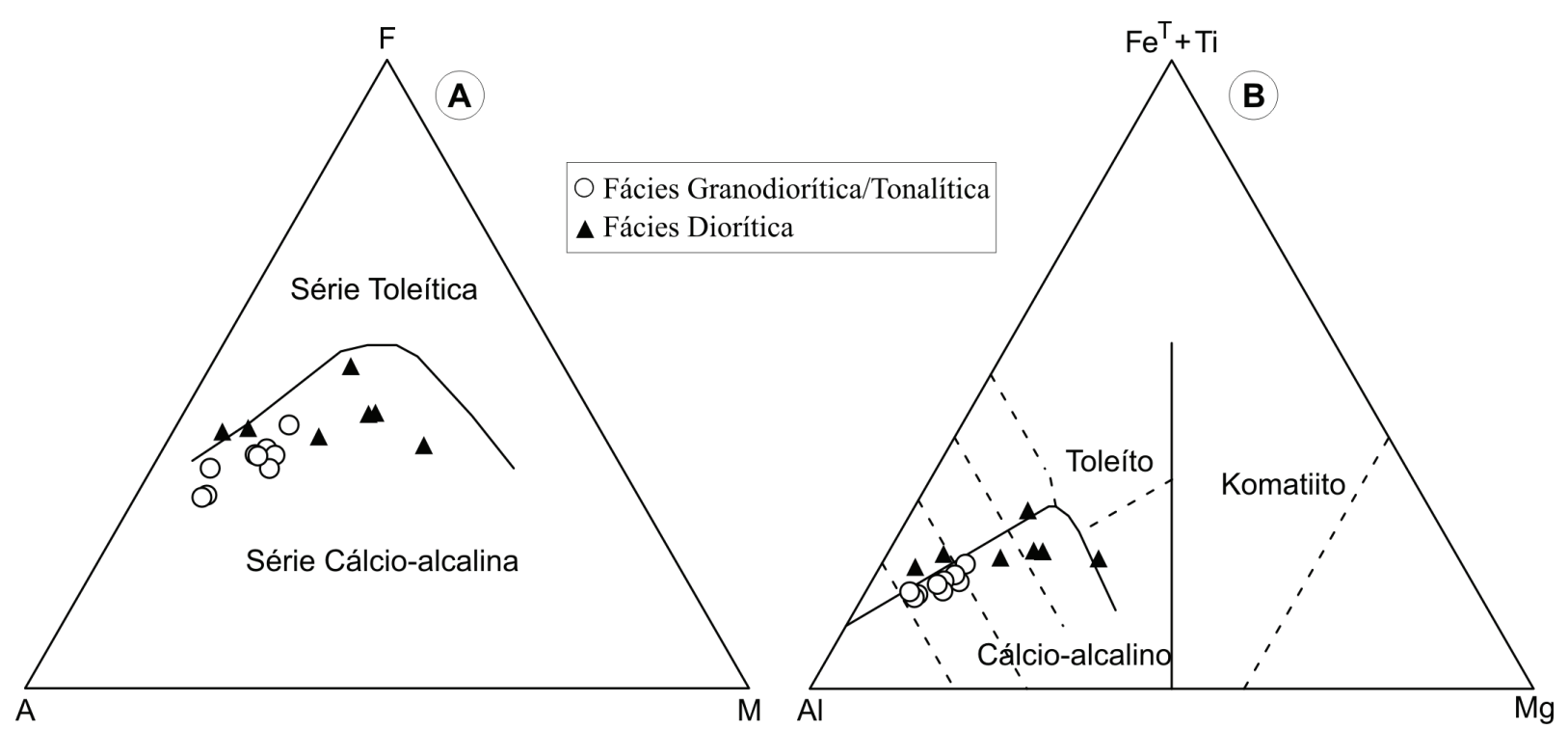

Figura 15. Definição da natureza cálcio-alcalina das rochas do Plúton Serra da Garganta, segundo (A) diagrama AFM (Irvine \& Baragar, 1971) e (B) diagrama de Jensen, modificado por Rickwood (1989).

Figure 15. Definition of calc-alkaline nature of rocks of the Serra da Garganta Pluton, according (A) AFM diagram (Irvine \& Baragar, 1971) and (B) Jensen diagram, modified from Rickwood (1989). 
do Plúton Serra da Garganta são de natureza cálcio -alcalina. Já no diagrama que relaciona sílica com a razão $\mathrm{K}_{2} \mathrm{O} / \mathrm{MgO}$ (em base logarítmica), proposto por Rogers \& Greenberg (1981) (Fig. 16B), tem-se também a confirmação de sua natureza cálcio-alcalina.

A figura 17A apresenta o diagrama de Frost et al. (2001) que relaciona a $\mathrm{SiO}_{2}$ com $\mathrm{Na}_{2} \mathrm{O}+\mathrm{K}_{2} \mathrm{O}-$ $\mathrm{CaO}$ classificando a rocha segundo sua alcalinidade. Para as rochas da fácies dioríticas a dispersão não permite a definição de uma associação magmática, diferentemente das rochas da fácies granodiorítica/tonalítica que mesmo com valores maiores de $\mathrm{SiO}_{2}$, plotam no campo das rochas cálcio-alcalinas. No diagrama da figura 17B, também de Frost et al. (2001), no caso relacionando $\mathrm{SiO}_{2}$ com $\mathrm{FeOtot} /\left(\mathrm{FeO}^{\text {tot }}+\mathrm{MgO}\right)$, com a linha divisória de $\mathrm{Fe}^{*}$ (que se aplica as análises de rochas tendo apenas quantidade total de $\mathrm{Fe}_{2} \mathrm{O}_{3 \mathrm{t}}$ ou $\mathrm{FeO}$ ) as rochas estudadas mostram-se de natureza magnesiana, com exceção de duas amostras da fácies diorítica, em virtude de seu mais elevado teor de FeO. A na-

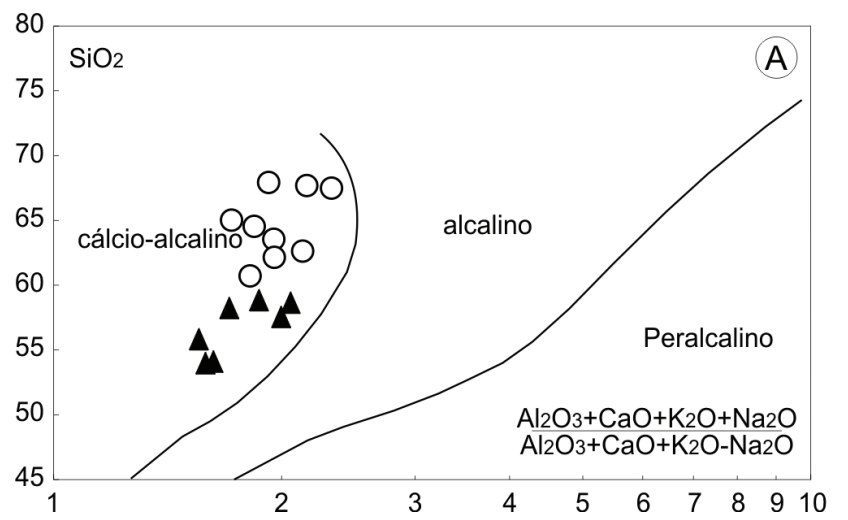

tureza magnesiana dessas rochas corrobora com a filiação cálcio-alcalina, como é defendido por Frost et al. (2001).

\subsubsection{Geocronologia}

A datação U-Pb, pelo método SHRIMP foi obtida a partir da análise de 15 grãos de zircões (Tab. 7), os quais se apresentam, de modo geral, bem formados, com cristais alongados (Fig. 18A), euédricos, com a maioria sem apresentar zonação/fraturas ou intercrescimento de borda (características de zircões ígneos). Esses zircões são provenientes da amostra ML-55 - um anfibólio-biotita granodiorito. Os zircões apresentam tamanhos que variam de $500 \mu \mathrm{m}$ a $100 \mu \mathrm{m}$ e razões axiais entre 1:1,5 e 1:4,0. Na catodoluminescência todos os grãos exibem zoneamento oscilatório marcado pela alternância de faixas claras e escuras (mais ricas em U). Os grãos são euédricos com o fino zoneamento acompanhando as faces dos cristais. Não foram identificados núcleos, bordas recristaliza-

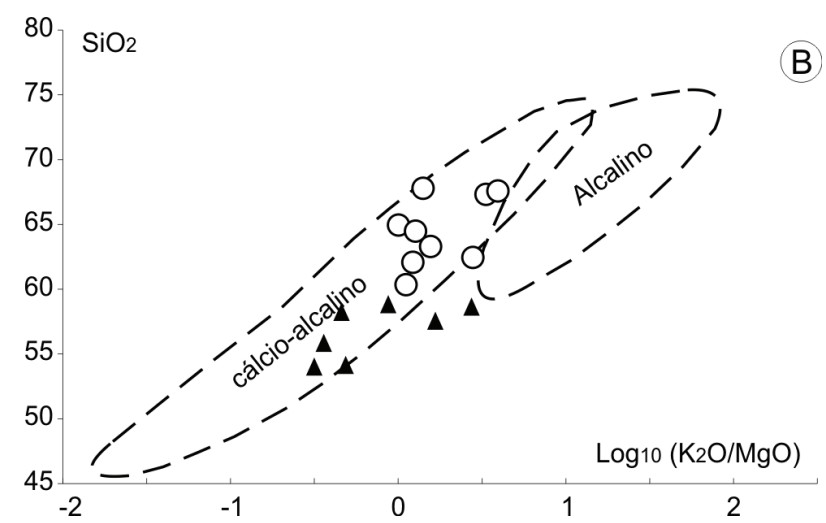

Figura 16. Diagramas utilizados na definição de séries magmáticas para as rochas do Plúton Serra da Garganta, segundo dois autores. A) Wright (1969); B) Rogers \& Greenberg (1981).

Figure 16. Diagrams used in the definition of magmatic series for rocks of the Serra da Garganta Pluton, according to two authors. A) Wright (1969); B) Rogers \& Greenberg (1981).
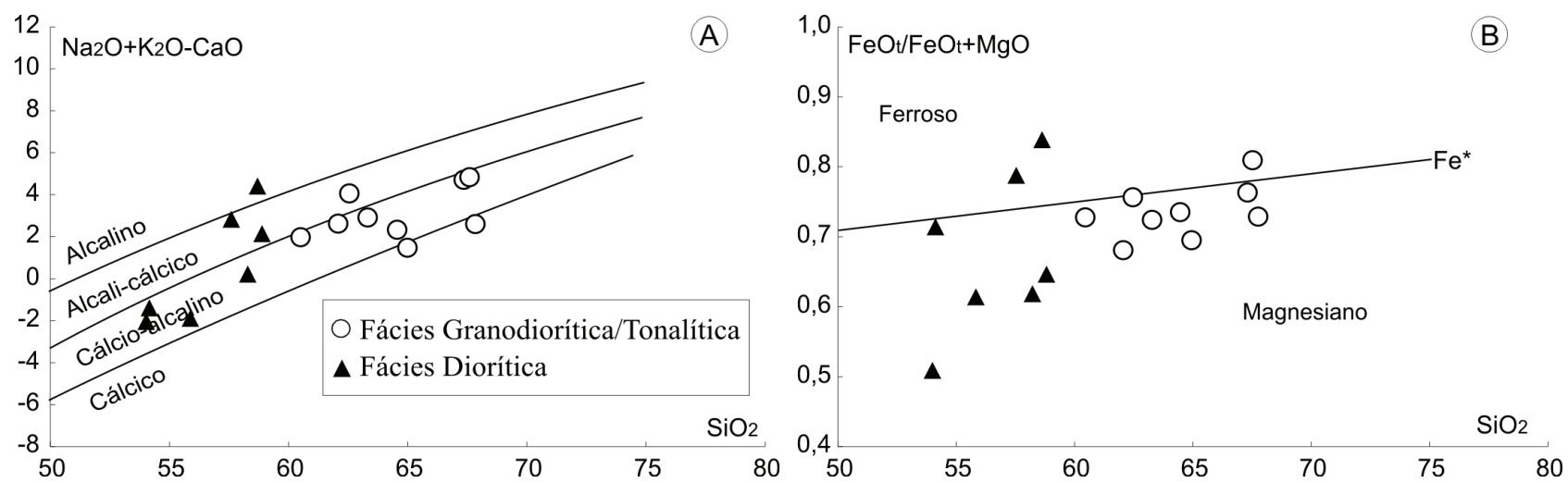

Figura 17. Diagramas utilizados na definição de séries magmáticas para as diferentes fácies do Plúton Serra da Garganta, segundo Frost et al. (2001). A) $\mathrm{SiO}_{2} \times \mathrm{Na}_{2} \mathrm{O}+\mathrm{K}_{2} \mathrm{O}-\mathrm{CaO}$; B) $\mathrm{SiO}_{2} \times \mathrm{FeO}_{\mathrm{t}} / \mathrm{FeO}_{\mathrm{t}}+\mathrm{MgO}$.

Figure 17. Diagrams used in the definition of magmatic series for the different facies of Serra da Garganta Pluton, according to Frost et al. (2001). A) SiO2 x Na2O+K2O-CaO; B) SiO2 x FeOt/FeOt+MgO. 
das ou setores com padrão de crescimento distinto da alternância regular de finas faixas claras e escuras. As razões Th/U são típicas de zircões ígneos, variando entre 0,45 a 0,88 (Williams et al., 1996). As análises agrupam-se para definir uma idade concórdia de $598 \pm 5$ Ma (MSWD = 0,37; Fig. 18B) idêntica a idade média 206Pb/238U (MSWD = $0,74)$. Esse resultado é interpretado como a idade de cristalização do zircão.

Tabela 7. Dados isotópicos U-Pb (SHRIMP) de grãos de zircões da fácies granodiorítica/tonalítica do Plúton de Serra da Garganta.

Table 7. Isotopic data U-Pb (SHRIMP) zircon grains of granodioritic/tonalitic facies of Serra da Garganta Pluton.

\begin{tabular}{|c|c|c|c|c|c|c|c|c|c|c|c|c|c|}
\hline $\begin{array}{l}\text { Grão } \\
\text { spot }\end{array}$ & $206 \mathrm{Pbc}$ & $\begin{array}{l}{ }^{232} \mathrm{Th} / \\
{ }^{238} \mathrm{U}\end{array}$ & $\begin{array}{c}{ }^{206} \mathrm{~Pb} * \\
\mathrm{ppm}\end{array}$ & $\begin{array}{l}{ }^{207} \mathrm{~Pb} * / \\
{ }^{235} \mathrm{U}\end{array}$ & $\begin{array}{c}\text { erro (\%) } \\
1 \sigma\end{array}$ & $\begin{array}{c}{ }^{207} \mathrm{~Pb}^{*} / \\
{ }^{238} \mathrm{U}\end{array}$ & $\begin{array}{c}\text { erro (\%) } \\
1 \sigma\end{array}$ & $\begin{array}{l}\text { erro } \\
\text { cor. }\end{array}$ & $\begin{array}{c}{ }^{206} \mathrm{~Pb} / \\
{ }^{238} \mathrm{U} \\
(\mathrm{Ma})\end{array}$ & $\begin{array}{l}\text { erro } \\
1 \sigma\end{array}$ & $\begin{array}{c}{ }^{207} \mathrm{~Pb}^{*} / \\
{ }^{206} \mathrm{~Pb}^{*} \\
(\mathrm{Ma}) \\
\end{array}$ & $\begin{array}{l}\text { erro } \\
1 \sigma\end{array}$ & $\begin{array}{c}\% \\
\text { disc. }\end{array}$ \\
\hline 1.1 & 0,50 & 0,76 & 18,3 & 0,81 & 5,0 & 0,0962 & 3,7 & 0,731 & 591,4 & 23,5 & 649 & 73 & 10 \\
\hline 2.1 & 1,44 & 0,59 & 36,8 & 0,80 & 6,5 & 0,0971 & 3,5 & 0,542 & 599,3 & 22,5 & 604 & 119 & 1 \\
\hline 3.1 & 0,51 & 0,48 & 45,3 & 0,83 & 4,9 & 0,1000 & 3,6 & 0,745 & 615,4 & 23,0 & 621 & 70 & 1 \\
\hline 4.1 & 0,51 & 0,48 & 23,8 & 0,84 & 5,1 & 0,0984 & 3,6 & 0,697 & 605,0 & 22,3 & 668 & 79 & 10 \\
\hline 5.1 & 1,16 & 0,59 & 27,1 & 0,79 & 6,3 & 0,0974 & 3,6 & 0,573 & 603,0 & 22,7 & 563 & 112 & -6 \\
\hline 6.1 & 0,50 & 0,51 & 30,8 & 0,81 & 4,9 & 0,0970 & 3,5 & 0,729 & 598,0 & 21,9 & 636 & 72 & 7 \\
\hline 7.1 & 0,24 & 0,79 & 51,5 & 0,81 & 4,0 & 0,0974 & 3,5 & 0,870 & 601,0 & 22,8 & 604 & 43 & 1 \\
\hline 8.1 & 0,78 & 0,47 & 16,8 & 0,82 & 5,5 & 0,1000 & 3,8 & 0,687 & 614,5 & 24,2 & 597 & 87 & -3 \\
\hline 9.1 & 0,71 & 0,56 & 17,3 & 0,77 & 6,3 & 0,0952 & 3,6 & 0,567 & 587,7 & 22,1 & 566 & 114 & -3 \\
\hline 10.1 & 0,46 & 0,45 & 90,0 & 0,78 & 4,0 & 0,0949 & 3,5 & 0,879 & 585,5 & 21,0 & 578 & 41 & -1 \\
\hline 11.1 & 1,16 & 0,49 & 16,4 & 0,82 & 7,5 & 0,0981 & 3,6 & 0,478 & 604,7 & 22,5 & 637 & 142 & 6 \\
\hline 12.1 & 2,56 & 0,61 & 17,0 & 0,81 & 11,6 & 0,0984 & 3,6 & 0,314 & 606,0 & 23,7 & 606 & 237 & 0 \\
\hline 13.1 & 0,64 & 0,66 & 26,5 & 0,79 & 4,9 & 0,0959 & 3,5 & 0,717 & 593,8 & 22,3 & 587 & 75 & -1 \\
\hline 14.1 & 0,45 & 0,79 & 24,1 & 0,79 & 5,8 & 0,0964 & 3,6 & 0,611 & 595,5 & 22,9 & 584 & 100 & -2 \\
\hline 15.1 & 0,78 & 0,88 & 11,5 & 0,81 & 9,2 & 0,0963 & 4,3 & 0,471 & 597,4 & 27,4 & 627 & 175 & 6 \\
\hline
\end{tabular}

Erro analítico $1 \sigma$, Pbc e $\mathrm{Pb}^{*}$ correspondem, respectivamente, chumbo comum e radiogênico;

Erro padrão $(2 \sigma)$ médio foi $2,27 \%$;

Idades corrigidas para ${ }^{204} \mathrm{~Pb}$.

(A)

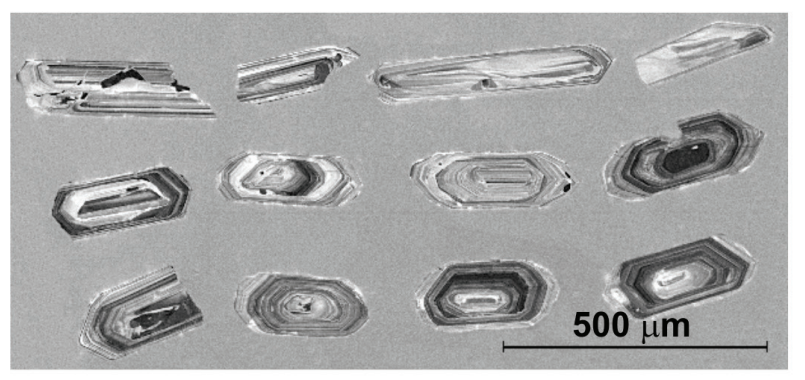

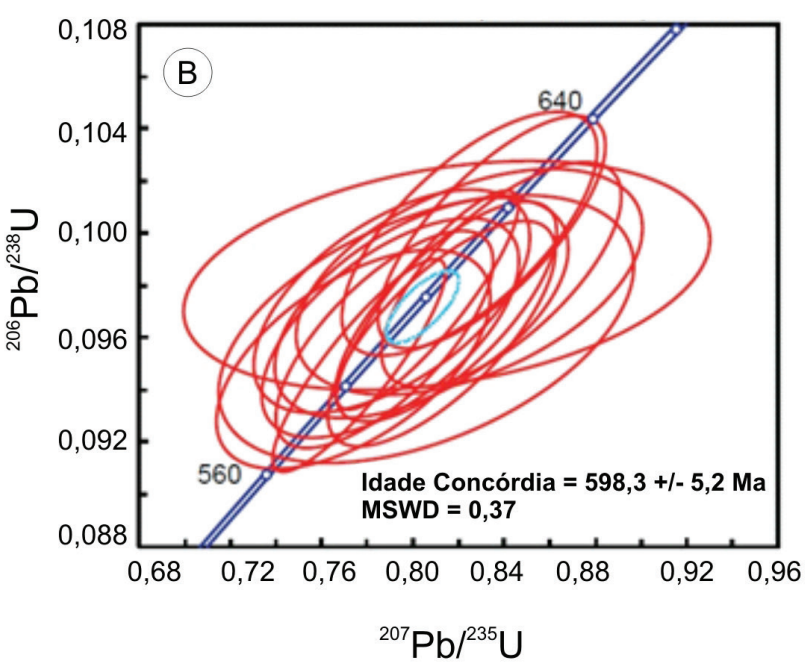

Figura 18. Zircões e idade da fácies granodiorítica/tonalítica do Plúton Serra da Garganta. Em (A) imagem de zircões mostrando cristais bem formados e alongados e (B) diagrama concórdia U/Pb com 15 zircões analisado.

Figure 18. Zircons and age of the granodioritic/tonalitic facies of the Serra da Garganta Pluton. In (A) imagem of zircons showing well shaped and elongated crystals and (B) U/Pb concordia diagram with 15 zircons analised. 


\section{Discussão dos resultados e conclusões}

A assembleia mineral das rochas da fácies granodiorítica/tonalítica, dominantes no plúton, é a mesma (plagioclásio, quartzo, K-feldspato, biotita, hornblenda, titanita, epídoto, allanita, minerais opacos, zircão e apatita), apenas as diferentes proporções modais entre as mesmas é que determinam duas diferentes litologias: granodiorito e tonalito, ainda que em campo/mapa estas duas unidades não sejam diferenciadas, refletindo a grande homogeneidade textural e de coloração dessas rochas (equigranulares de textura média, com raros fenocristais de plagioclásio, e no geral com $\Sigma \mathrm{M}=25-35 \%$ ).

Por sua vez as rochas dioríticas são bastante homogêneas, textural e composicionalmente. Elas ocorrem exclusivamente como enclaves quartzo dioríticos apresentando feições de coexistência (mingling) no estado magmático com a encaixante (fácies granodiorítica/tonalítica). Plagioclásio é a fase mineral dominante, seguido por biotita, hornblenda e quartzo, enquanto que K-feldspato, titanita, epídoto, allanita, minerais opacos, zircão e apatita ocorrem como acessórios.

Em ambas as fácies (granodiorítica/tonalítica e diorítica) as relações microtexturais petrográficas indicam que apatita e zircão são as fases minerais mais precoces, seguidas por minerais opacos e allanita, e finalmente por epídoto e titanita. Anfibólio e biotita são os máficos mais tardios. Na assembleia félsica o plagioclásio é mais precoce e K-feldspato e quartzo mais tardios.

A presença de biotita e hornblenda como principais minerais máficos nestas rochas, e de cristalização precoce em relação aos feldspatos e ao quartzo, sugere um magma parental enriquecido em $\mathrm{H}_{2} \mathrm{O}$. Allanita precoce e usualmente com coroas de epídoto sugere condições de fugacidade de oxigênio moderada, pelo menos acima do tampão FMQ o que é corroborado pela presença da paragênese magmática titanita+quartzo+magnetita em equilíbrio (Wones, 1989).

Fluidos hidrotermais tardios são responsáveis por transformação de biotita para clorita e/ou muscovita, de feldspatos para mica branca e carbonato, além de manteamento de minerais opacos por titanita. Por outro lado a presença de mirmequita, restrita nas rochas dioríticas e relativamente pouco desenvolvida nas granodioríticas/ tonalíticas, as quais são empobrecidas em K-feldspatos, sugere baixo volume de fluidos aquosos no sistema (Hibbard, 1979). A presença de pertitas (tipos fios e/ou filetes), feição comum nos cristais de K-feldspato das fácies granodioríticas/tonalíticas, indica que a temperatura do solvus $(\leq 6000 \mathrm{C})$ foi atingida em estágio tardio da cristalização/ resfriamento do granito. Por sua vez o caráter subsolvus (presença de dois feldspatos distintos na fácies granodiorítica/tonalítica) é um indicativo de pressão de cristalização de pelo menos $\geq 3,0$ kbar, como já indicado pelo geobarômetro de Schmidt (1992).

Um aspecto petrográfico marcante no Plúton Serra da Garganta é a forte zonação dos plagioclásios (zonação normal e oscilatória, patchy zoning e synneusis), indicando que a cristalização fracionada foi um processo importante durante a evolução do magma que deu origem ao Plúton Serra da Garganta. De acordo com Vance (1965, 1969), Smith (1974), Hibbard (1995) e Vernon (2004), estas microtexturas podem ter diferentes interpretações, mas são essencialmente de caráter magmático. A presença ainda de xenocristais com bordas de reação/absorção é evidência microtextural de processos de mistura de magmas (mingling) entre as rochas dioríticas e granodioríticas/ tonalíticas, já constatado por feições de campo.

A composição da biotita nas rochas da fácies granodiorítica/tonalítica indica que o magma progenitor dessas rochas possui afinidade com suítes orogênicas cálcio-alcalinas do tipo-I, no sentido de Abdel-Rahman (1994). Suas razões Fe/ $(\mathrm{Fe}+\mathrm{Mg}) \approx 0,5$ sugerem condições de fugacidade de oxigênio acima do tampão FMQ ou seja, mais oxidantes (Wones \& Eugester, 1965, Lalonde \& Bernard, 1993, Galindo et al., 2012), o que ainda é consistente com a presença da associação titanita+magnetita+quartzo (Wones, 1989). 0 desenvolvimento local de cloritização ao longo de planos de clivagens da biotita primária indica ação de fluidos aquosos tardios, num processo subsolidus tardi-magmático. Composições tipicamente magmáticas são ainda observadas nos baixos teores de alumínio $\left(\mathrm{Al}_{2} \mathrm{O}_{3}=1,97-2,81 \%\right.$,) e nos baixos teores de flúor $(\mathrm{F}<1 \%)$ e $\mathrm{Al}_{(\mathrm{t})}+\mathrm{Fe}_{3}+(<0,2)$ das titanitas 
(Tulloch, 1979; Enami et al., 1993; Galindo et al., 2012). Por outro lado, as finas e irregulares coroas de titanita localmente circundando minerais opacos podem estar associadas a processos tardios de hidratação em condições de alta $\mathrm{fH}_{2} \mathrm{O}$ (Harlov et al., 2006).

As características químicas mostram que ambas as fácies são relativamente distintas quando comparadas aos corpos granitoides da porção setentrional da Província Borborema. O Plúton Serra da Garganta distingue-se por sua natureza cálcio-alcalina, caráter magnesiano, metaluminoso a peraluminoso, além de padrões de ETR com enriquecimento em ETRL com relação aos ETRP. Um fracionamento importante de feldspatos, combinado a variadas proporções de anfibólio, pode explicar essas feições. No tocante às rochas da fácies diorítica, estas ocorrem como enclaves máficos na fácies granodiorítica/tonalítica, sendo interpretados como enclaves máficos microgranulares, que representariam a porção menos evoluída do magma parental do Serra da Garganta injetados e aprisionados no hospedeiro félsico. De acordo com a literatura (Jardim de Sá, 1994; Mariano et al., 2001; Nascimento et al., 2002), rochas básicas a intermediárias (dioritos) e ácidas (granitos) que ocorrem associadas em diferentes plútons no extremo nordeste da Província Borborema (plútons Acari e Itaporanga, por exemplo) refletem a distinção de diferentes magmas, diferentemente do Plúton Serra da Garganta, no qual é claro que as duas fácies tiveram uma evolução comum com termos menos evoluídos (a fácies diorítica) passando para mais evoluídos (a fácies granodiorítica/tonalítica). Ambas, portanto, de afinidade cálcio-alcalina.

Zircões de uma amostra da fácies granodiorítica/tonalítica apresentaram uma marcante uniformidade nas razões isotópicas do sistema U$\mathrm{Th}-\mathrm{Pb}$, com uma concórdia fornecendo idade de $598 \pm 5$ Ma. Idades U-Pb em zircão em torno de 590 e 600 Ma para rochas graníticas no Domínio Rio Piranhas - Seridó estão documentadas nos plútons Totoró (591 Ma; Archanjo et al., 2013) e Cardoso (596 Ma; Hollanda et al., 2015). Como no plúton de Serra da Garganta, os corpos de Totoró e Cardoso são intrusivos em metapelitos da Formação Seridó, mostrando que mesmos corpos de afinidades químicas distintas possuem idades de cristalização semelhantes.

Agradecimentos. Os autores agradecem a CPRM - Serviço Geológico do Brasil, pela autorização na divulgação de dados apresentados neste trabalho, o apoio do projeto "Parametrização de afloramentos do embasamento cristalino das bacias do Ceará e interiores do trend Cariri-Potiguar para estudos de condutividade térmica: um tema em continuidade" (UFRN/PETROBRAS-CENPES/FUNPEC) e a Maria Helena Hollanda (IGc/USP) pelo suporte analítico. Somos gratos também aos revisores (Valdecir A. Janasi e Lauro V. Nardi) pelas sugestões e discussões que possibilitaram melhoras significativas no artigo.

\section{Referências bibliográficas}

Abdel-Rahman, A.M. 1994. Nature of biotites from alkaline, calc-alkaline, and peraluminous magmas. Journal of Petrology, 35: 525-541.

Almeida, F.F.M., Brito Neves, B.B. \& Fuck, R. 1981. Brazilian structural provinces: an introduction. Earth-Science Reviews, 17: 1-29.

Almeida, F.F.M., Leonardos Jr., O.H. \& Valença, J. 1967. Review on granitic rocks of northeast South America. Haarlem: International Union of Geological Sciences, 41p.

Angelim, L.A.A., Nese, F.R., Torres, H.H.F., Medeiros, V.C., Santos, C.A., Veiga Junior, J.P. \& Medendes, V.A. 2006. Geologia e recursos minerais do Estado do Rio Grande do Norte, Escala 1:500.000. Recife: CPRM - Serviço Geológico do Brasil.

Archanjo, C.J., Viegas, L.G.F., Hollanda, M.H.B.M., Souza, L.C. \& Liu, D. 2013. Timing of the HT/ LP transpression in the Neoproterozoic Seridó Belt (Borborema Province, Brazil): Constraints from $\mathrm{U} \backslash \mathrm{Pb}$ (SHRIMP) geochronology and implications for the connections between NE Brazil and West Africa. Gondwana Research, 23: 701714.

Black, L.P., Kamo, S.L., Allen, M.C., Davis, D.W., Aleinikoff, J.N., Valley, J.W. \& Mundif, R., Campbell, I.H., Korsch, R.J., Williams, I.S. \& Foudoulis, C. 2004. Improved ${ }^{206} \mathrm{~Pb} /{ }^{238} \mathrm{U}$ microprobe geochronology by monitoring of a trace element related matrix effect; SHRIMP, ID-TIMS, ELA-ICP-MS and oxygen isotope documentation for 
a series of zircon standards. Chemical Geology, 205: 115-140.

Blundy, J.D. \& Holland, T.J.B. 1990. Calcic amphibole equilibria and a new amphibole-plagioclase geothermometer. Contribution to Mineralogy and Petrology, 104: 208-224.

Costa, L.S., Galindo, A.C., Alves da Silva, F.C. \& Silva Neto, M.F. 2015. 0 stock granítico Serra Verde: exemplo do magmatismo granítico cálcio alcalino no Domínio Rio Grande do Norte, NE da Província Borborema. Geologia USP: Série Científica, 15(3): 41-56.

Deer, W.A., Howie, R.A. \& Zussman, J. 2013. An Introduction to the Rock-forming minerals. Third Ed. The Mineralogical Society, London, 498p.

Enami, M., Suzuki, K., Liou, J.G. \& Bird, D.K. 1993. $\mathrm{Al}-\mathrm{Fe} 3+$ anf $\mathrm{F}-\mathrm{OH}$ substitution in titanite and constraints on their P-T dependence. European Journal of Mineralogy, 5: 219-231.

Evensen, N.M., Hamilton, P.J. \& Onions, R.K. 1978. Rare-Earth abundances in chondritic meteorites. Geochimica et Cosmochimica Acta, 42(8): 1199-1212.

Ferreira, V.P., Sial, A.N. \& Jardim de Sá, E. F. 1998. Geochemical and isotopic signature of Proterozoic granitoids in terranes of the Borborema structural province, northeastern Brazil. Journal of South American Earth Sciences, 11: 439455.

Frost, B.R., Barnes, C.G., Collins, W.J., Arculus, R.J., Ellis, D.J. \& Frost, C.D. 2001. A geochemical classification for granitic rocks. Journal of Petrology, 42(11): 2033-2048.

Galindo, A.C., Dall'Agnol, R., McReath, I., Leterrier, J. \& Nascimento, M.A.L. 1997a. Granitoide Quixaba: um magmatismo monzonítico (shoshonítico?) no extremo oeste da Faixa Seridó. In: SIMPÓSIO DE GEOLOGIA DO NORDESTE, 17, 1997, Fortaleza, Boletim ... Fortaleza, p. 268-272.

Galindo, A.C., Jardim de Sá, E.F., Nascimento, R.S.C., Hollanda, M.H.B.M., Nascimento, M.A.L. \& Lardeaux, J.M. 1997b. Caracterização geoquímica e contexto geodinâmico dos granitoides alcalinos na porção oriental da Faixa Seridó (RN-PB). In: SIMPÓSIO DE GEOLOGIA DO NORDESTE, 17, 1997, Fortaleza, Boletim ... Fortaleza, p. 263267.

Galindo, A.C., Alves da Silva, F.C. \& Souza, Z.S. 2012.
Química mineral de leucomicrogranitos neoproterozóicos do Domínio Rio Grande do Norte (DRN). Geochimica Brasiliensis, 26(1): 19-28.

Harlov, D., Tropper, P., Seifert, W., Nijland, T. \& Forster, H-J. 2006. Formation of Al-rich (CaTi$\mathrm{SiO}_{4} \mathrm{O}-\mathrm{CaAlSiO}{ }_{4} \mathrm{OH}$ ) reaction rims on ilmenite in metamorphic rocks as function of $\mathrm{fH}_{2} \mathrm{O}$ and $\mathrm{fO}_{2}$. Lithos, 88: 72-84.

Hibbard, M.J. 1979. Myrmekite as a marker between preaqueous and postaqueous phase saturation in granitic system. Geological Society America Bulletin, 90: 1047-1062.

Hibbard, M.J. 1995. Petrography to petrogenesis. Pretence Hall, New Jersey, 587p.

Hollanda, M.H.B.M., Archanjo, C.J., Bautista, J.R. \& Souza, L.C. 2015. Detrital zircon ages and Nd isotope compositions of the Seridó and Lavras da Mangabeira basins (Borborema Province, NE Brazil):Evidence for exhumation and recycling associated with a major shift in sedimentary provenance. Precambrian Research, 258: 186-207.

Irvine, T.N. \& Baragar, W.R.A. 1971. A guide to the chemical classification of the common volcanic rocks. Canadian Journal Earth Science, 8: 523548.

Jardim de Sá, E.F. 1994. A Faixa Seridó (Província Borborema, NE do Brasil) e o seu significado geodinâmico na Cadeia Brasiliana/Pan-Africana. Brasília, 803p. Tese de Doutorado, Programa de Pós-Graduação em Geociências, Universidade de Brasília.

Jardim de Sá, E.F., Legrand, J.M. \& McReath, I. 1981. "Estratigrafia" de rochas granitoides na região do Seridó (RN-PB) com base em critérios estruturais. Revista Brasileira de Geociências, 11: 50-57.

Lalonde, A.E. \& Bernard, P. 1993. Composition and coloro $\mathrm{f}$ biotites from granites:two useful properties in the characterization of plutonic suites from the Hepburn internal zone of wopmay orogen, northwest territories. Canadian Mineralogist, 31: 203-217.

Lameyre, J. \& Bowden, P. 1982. Plutonic rock type series: discrimination of various granitoids series and related rocks. Journal of Volcanology and Geotermal Research, 14: 169-186. 
and Glossary of Terms. Recommendations of the International Union of Geological Sciences Subcommission on the Systematics of Igneous Rocks. Cambridge University Press, 2nd ed., 236p.

Leake, B.E., Wooley, A.R., Arps, C.E.S, Birch, W.D., Gilbert, M.C., Grice, J.D., Hawthorne, F.C., Kato, A., Kisch, H.J., Krivovichev, V.G., Linthou, K., Laird, J., Mandarino, J.A., Maresch, W.V., Nickel, E.H, Schumacher, J., Smith, J.C., Stephenson, N.C.N., Ungaretti, L., Whittaker, E.J.W. \& Youzhi, G. 1997. Nomenclature of Amphiboles: Report of the Subcommittee on Amphiboles of the International Mineralogical. Mineralogical Magazine, 61: 295-231.

Ludwig, K.R. 2003. Isoplot 3.00: A Geochronological Toolkit for Microsoft Excel@ (Revised Version), vol. 4. Berkeley Geochronological Center, Special Publication, Berkeley, CA.

Maniar, P.D. \& Piccoli, P.M. 1989. Tectonic discriminations of granitoids. Geological Society of America Bulletin, 101: 635-643.

Mariano, G., Neves, S.P., Silva Filho, A.F. \& Guimarães, I.P. 2001. Diorites of the High-K Calc-Alkalic Association: Geochemistry and Sm-Nd Data and Implications for the Evolution of the Borborema Province, Northeast Brazil. International Geology Review, 43: 1-9.

Medeiros, V.C. 2013. Geologia da Província Mineral Seridó. In: SEMINÁRIO DAS PROVÍNCIAS METALOGENÉTICAS BRASILEIRAS: A PROVÍNCIA DE W-AU SERIDÓ. 1. Currais Novos. Serviço Geológico do Brasil - CPRM. CD-ROM, 2013, p. 2-15.

Medeiros, V.C., Nascimento, M.A.L., Dantas, E.L. \& Cunha, A.L.C. 2012. Currais Novos (SB.24-Z-B-II). Escala 1:100.000, Recife, Companhia de Pesquisa e Recursos Minerais.

Nascimento, M.A.L., Souza, Z.S., Galindo, A.C., Hollanda, M.H.B.M. \& Pimentel, M.M. 2002. Evidências de enriquecimento mantélico em rochas gabro-monzoníticas de Casserengue (PB) no extremo Nordeste da Província Borborema. Geochimica Brasiliensis, 16(1): 49-65.

Nascimento, M.A.L., Medeiros, V.C. \& Galindo, A.C. 2015. Ediacaran to Cambrian magmatic suites in the Rio Grande do Norte domain, extreme Northeastern Borborema Province (NE of Brazil): current knowldge. Journal of South American Earth Sciences, 58: 281-299.
Oliveira, M.T.D., Nascimento, M.A.L. \& Galindo, A.C. 2014. Definição de suítes magmáticas em corpos ediacaranos no extremo NE da Província Borborema (Estado do Rio Grande do Norte): Plútons Pitombeira, Taipu e Gameleira. Geologia USP: Série Científica, 14(4), 61-80.

Rickwood, P.C. 1989. Boundary lines within petrologic diagrams which use oxides of major and minor elements. Lithos, 22: 247-263.

Rogers, J.J.W. \& Greenberg, J. K. 1981. Trace elements in continental margín magmatism. Part III Alkali granites and their relationships to cratonization. Geological Society of America Bulletin, 92(1): 6-9.

Sato, K., Tassinari, C.C.G., Basei, M.A.S., Siga Jr., O., Onoe, A.T. \& Souza, M.D., 2014. Sensitive High Resolution Ion Microprobe (SHRIMP IIe/MC) of the Institute of Geoscience of the University of São Paulo, Brazil: analytical method and first results. Geologia USP: Série Científica, 14(3): 3-18.

Schmidt, M.W. 1992. Amphibole composition in tonalites as a function of pressure: an experimental calibration of the Al-in-hornblende barometer. Contribution to Mineralogy and Petrology. 110: 304-310.

Sial, A. N. 1987. Granitic rocks in northeast Brazil. In: INTERNATIONAL SYMPOSIUM ON GRANITES AND ASSOCIATED MINERALIZATIONS. 2, Salvador. Excursion guides, 1987, p. 61-69.

Smith, J.V. 1974. Feldspar Minerals. Berlim, Springer-Verlag, 690p.

Stacey, J.S. \& Kramers, J.D., 1975. Approximation of terrestrial lead isotope evolution by a two-stage model. Earth and Planetary Science Letters, 26: 207-221.

Streckeisen, A.L. 1976. To each plutonic rock its proper name. Earth Science Reviews, 12: 1-33.

Tulloch, A.J. 1979. Secondary Ca-Al silicates as lowgrade alteration products of granitoid biotite. Contributions Mineralogy and Petrology, 69: 105-117.

Vance, J.A. 1965. Zoning in igneous plagioclase: patchy zoning. Journal of Geology, 73(4): 636-651.

Vance, J.A. 1969. On synneusis. Contributions to Mineralogy and Petrolology, 24: 7-29.

Vernon, R.H. 2004. A pratical guide to rock microstructure. Cambridge, Cambridge University 
Press, 594p.

Williams, I.S., Buik, I.S. \& Cartwright, I., 1996. An extended episode of early Mesoproterozoic fluid flow in the Reynolds Range, Central Australia. Journal of Metamorphic Geology, 14: 2947.

Wones, D.R. 1989. Significance of the assemblage titanite + magnetite + quartz in granitic rocks. American Mineralogist, 74: 744-749.

Wones, D.R. \& Eugster, H.P. 1965. Stability of biotite: experiment, theory, and application. The American Mineralogist, 50: 1228-1272.

Wright, J.B. 1969. A simple alkalinity ratio and its application to questions of non-orogenic granite genesis. Geological Magazine, 106: 370-384. 